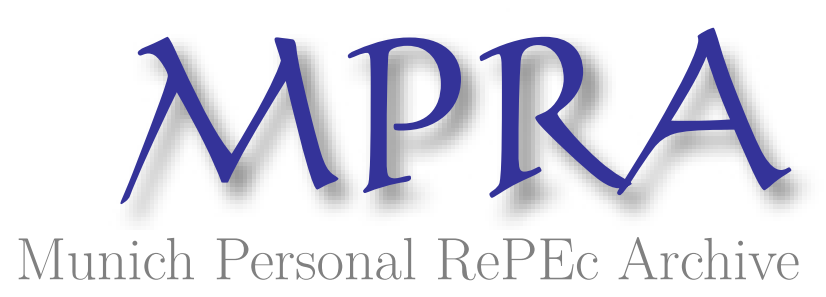

\title{
Democracy, Institutions, and International Profit-Shifting
}

Delis, Fotios and Economidou, Claire and Hasan, Iftekhar

Department of Economics, University of Piraeus, Department of Economics, University of Piraeus, Fordham University, Bank of Finland, and University of Sydney

28 January 2022

Online at https://mpra.ub.uni-muenchen.de/111715/ MPRA Paper No. 111715, posted 29 Jan 2022 16:56 UTC 


\title{
Democracy, Institutions, and International Profit-Shifting*
}

\author{
Fotis Delis \\ Department of Economics, University of Piraeus \\ 80, M. Karaoli \& A. Dimitriou St., 18534 Piraeus, Greece \\ E-mail:f.ntel7@gmail.com \\ Claire Economidou \\ Department of Economics, University of Piraeus \\ 80, M. Karaoli \& A. Dimitriou St., 18534 Piraeus, Greece \\ E-mail: economidou@unipi.gr \\ Iftekhar Hasan \\ Fordham University, Bank of Finland, and University of Sydney \\ 45 Columbus Avenue, $5^{\text {th }}$ Floor \\ New York, NY 10023 \\ E-mail: ihasan@fordham.edu
}

\footnotetext{
* We are grateful to Seraina Anagnostopoulou, Bertrand Candelon, Alexandros Bechlioulis, Manthos Delis, Dimitris Gounopoulos, Müge Karacal, Dimitris Karamanis, Dimitris Konstantios, Mark Sanders, Emmanuel Tsiritakis and the participants at the Economic Research Seminars of the University of Piraeus for useful comments and insights. The usual disclaimer applies.
} 


\title{
Democracy, Institutions, and International Profit-Shifting
}

\begin{abstract}
Does constitutional democratization affect profit-shifting strategies among firms? Using a global sample of multinational enterprises, we develop a subsidiary-year measure of profit-shifting and examine how this measure responds to changes in constitutional democracy and the subsequent evolution of the host country's institutions. Our main findings show that a one-standard-deviation increase in the Polity IV democracy index yields an approximately $37 \%$ decrease in profit-shifting to other countries. Protection of property rights, contract enforcement, and superior regulatory quality emerge as the key institutional channels that define the decision to keep profits at home. Our results are robust to an instrumental variables approach and a large battery of additional robustness tests.
\end{abstract}

JEL Classification : E02; H26; M48; O50

Keywords: profit shifting; multinational enterprises; democracy; institutions; non parametric 


\section{Introduction}

Globalization forces countries to compete for capital. By cutting their tax rates, economies attract more capital, which can boost investment and economic growth. Additionally, over the last few decades, corporate tax rates declined dramatically; the global average statutory corporate tax rate fell from $49 \%$ in 1985 to $24 \%$ in 2018 (Tørsløv et al., 2018). To benefit from corporate tax differences across countries, multinational enterprises (MNEs) "shift" profits from high-tax jurisdictions to low-tax jurisdictions in order to increase net profits. Such strategies erode the government revenue bases of high-tax jurisdictions and pose welfare and fiscal challenges for policymakers and international bodies (e.g., the OECD).

Our study suggests that in deciding to shift profits, MNEs and their subsidiaries not only consider how lucrative the tax-arbitrage is, but also, they examine whether shifted profits are safe and whether tax payments are easy to handle. Constitutional democracy and its qualitative characteristics could be the bedrock, as they provide the environment that allows people and businesses to communicate freely, collaborate, and flourish together. Differently phrased, constitutional democracy is the umbrella that triggers the process of institutional development and provides the first cell for the evolution of institutions that might affect profit shifting. Thus, our first hypothesis suggests that constitutional democracy at home limits MNEs' incentives to shift profit abroad.

The evolution of constitutional democracy sets the pathway for the development of democratic institutions. Such institutions, take the form of property rights, quality of governance, control for corruption, rule of law, etc. Specifically, contract form and enforcement, as well as common commercial codes and availability of information - all of which reduce the costs of transactions, risk, and uncertainty — are important factors in business operations. In this sense, 
countries' institutional environments may be important determinants of firms' profit-shifting strategies. Therefore, our second hypothesis notes that, following the constitutional democratization process, the evolution of specific institutions also affects profit shifting aggressiveness.

We test our hypotheses using global data on profit-shifting at the subsidiary-year level. To this end, we first estimate profit-shifting by subsidiary-year over 2009-2017, following the approach of Delis et al. (2021) and Delis et al. (2022). This approach builds on Huizinga and Laeven (2008), who examine how subsidiaries' logged earnings respond to changes in composite tax rates for the subsidiary and foreign countries. Specifically, a negative subsidiary earnings response to a positive change in the composite tax rate (the difference between the domestic corporate tax rate and the tax rates in all other countries in which an MNE has subsidiaries) shows that subsidiaries engage in profit shifting. The nonparametric estimation of this model provides profit-shifting estimates for all observations (subsidiary-years) in the data. ${ }^{1}$

Subsequently, we examine the response of profit shifting to changes in democracy. Our sample for this analysis includes only the subsidiary-year observations for which we identify profitshifting and for which data on all important variables are available $(6,590$ subsidiaries from 57 countries over 2009-2017). Establishing a causal relation between democratic development and profit-shifting is a key objective of our paper.

The fact that we observe profit-shifting at the subsidiary-year level is a first remedy of the identification problem, because we control for important subsidiary and MNE characteristics as well as country-year variables that affect profit-shifting. A second remedy is the use of country, industry, year, and even subsidiary fixed effects. Fielding country fixed effects, in particular, yields

\footnotetext{
${ }^{1}$ There is also the work of De Simone et al. (2019), who develop an MNE-year score of profit shifting and study its relationship with corporate investment, but only for the case of the US.
} 
identification from a change (advancement or reversal) in the democracy indicators. To the extent that such a change is not systematically correlated with within-country time-varying unobserved variables, OLS estimates are consistent and unbiased.

To further insulate our analysis from the possibility of endogeneity bias, we additionally use an instrumental variables (IV) approach. Our instrument is drawn from Acemoglu et al. (2019), who uses regional waves of democratizations and reversals. The premise is that regional democratization affects profit-shifting only via its effect on democracy, given controls and fixed effects (thus satisfying the exclusion restriction).

Our findings from several robustness tests and measures of democracy clearly demonstrate that democracy matters. Our benchmark results using the constitutional Polity IV measure of democracy show that a one-standard-deviation increase in democracy in a subsidiary's country reduces profit-shifting to other countries by approximately $37 \%$. The economic significance of this effect is very large, making democratic development one of the most important determinants of profit-shifting.

We next examine the institutional channels through which constitutional democracy affects profit-shifting. We find that the ability of governments to protect property rights and enforce contracts, as well as high-quality policy-making capacity, are important channels that define subsidiaries' decisions to keep profits at home, even if there are lower-tax alternatives elsewhere. By improving institutional conditions instead of focusing on tax competition, governments could not only foster business activity at home but they can also ease future fiscal concerns and improve social welfare. However, we should also note that when loading institutions in the same empirical model with the constitutional democracy variable, the significant effect of constitutional democracy still prevails. This finding is in line with our hypothesis that constitutional democracy is the first cell, the umbrella that matters most. 
Although voluminous literature exists on the determinants of profit-shifting with special emphasis on taxation (Dharmapala and Riedel, 2013; Weichenrieder 2009; Klassen et al., 1993), there is a dearth of evidence on how constitutional democracy and institutions affect profit-shifting decisions. The most relevant comes from Sugathan and George (2015), which based on a sample of firms in India during 2001-2010 finds that institutional quality and corporate governance dissuade MNEs to shift their profits.

Our paper relates to and adds to various strands in the literature. In particular, the studies closer to our objectives are those on the determinants of profit-shifting (e.g., Dyreng and Markle, 2016; Markle, 2016; De Simone, 2016). These studies focus on how country characteristics affect profit-shifting (e.g., territorial versus worldwide systems, country-level institutions), as well as how characteristics of a firm's environment affect profit-shifting (e.g., financial reporting pressures, capital constraints, foreign ownership). Our study also relates to a strand of literature that takes a macro perspective to study MNEs' profit-shifting. The majority of this macro literature focuses on U.S. multinationals (Clausing, 2009, 2016; Gravelle, 2009; Zucman, 2014; Guvenen et al., 2019).

Moreover, our study adds to the literature on the estimation of profit-shifting. In a seminal contribution to the identification of profit-shifting, Hines and Rice (1994) examine income shifts between parents and subsidiaries, considering their countries' tax rate differentials. Subsequent studies allow for tax-rate differentials across countries for all subsidiaries in the same group (Huizinga and Laeven, 2008) or take a different perspective in estimating profit-shifting by identifying differences between the locations of firm sales and earnings (Dyreng and Markle, 2016). Dharmapala and Riedel (2013) examine exogenous shocks to multinational parent profits to infer the amount of profit shifted to low-tax subsidiaries. We extend this line of research by constructing a subsidiary-year measure of international profit-shifting for a large panel of countries 
around the world.

The remainder of the paper proceeds as follows. Section 2 introduces our theoretical framework on the role of democracy and underlying institutions on profit-shifting. Section 3 discusses the method to estimate profit-shifting and our empirical model linking profit-shifting to democracy. Section 4 analyzes the empirical results, and section 5 concludes the paper.

\section{Theoretical Framework}

Thus far, there is no literature on the role of democracy on international profit shifting. ${ }^{2}$ The latter, falls into the category of tax-avoidance tactics but differs in the following ways: (i) it requires an international network of affiliates; (ii) it navigates a complex set of laws and regulations that permit firms to reduce their domestic tax bases and allow foreign countries to tax these earnings (Desai and Dharmapala, 2009); and (iii) it is not necessarily illegal. Thus, MNEs exploit loopholes and ambiguities in tax laws of different countries, making it impossible for a single country to confront profit-shifting on its own. Along the same lines, profit-shifting usually is legal and thus bears lower costs, raising MNEs' incentives to engage in more aggressive profit-shifting. These distinguishing elements of profit-shifting, compared to other tax-planning strategies, generate a research question about whether democratic conditions, as an institutional umbrella, play a role on shaping profitshifting.

\footnotetext{
2 The literature on democracy and economics largely evolves around the effect of democracy on economic outcomes. As long as democracy has existed, there have been skeptics - from Plato warning of mass rule, to contemporary critics claiming authoritarian regimes can fast-track economic programs. Real-world examples (e.g., China) and academic research (Gerring et al., 2005) suggest that the effect of democracy on economic outcomes is at best ambiguous. On one hand, research that relies on cross-country comparisons questions the relationship between democracy and positive economic outcomes (Sirowy and Inkeles, 1990; Przeworski and Limongi, 1993; Helliwell, 1994; Barro, 1996; Tavares and Wacziarg, 2001). On the other hand, more recent studies that exploit both time series and cross-country variability find that democracy has a sizable effect on prosperity (Rodrik and Wacziarg, 2005; Papaioannou and Siourounis, 2008; Persson and Tabellini, 2009; Acemoglu, et al., 2013).
} 


\subsection{Constitutional Democracy and Tax-Related Profit-Shifting}

Recent theories developed by Acemoglu and Robinson (2000, 2006) argue that political (democratic) reforms can be viewed as strategic decisions by the political elite to prevent widespread social unrest and revolution. Political transition, rather than redistribution under existing political institutions, occurs because current transfers do not ensure future transfers, while the extension of the franchise changes future political equilibria and acts as a commitment to redistribution. More recent works such as those of Aidt and Jensen (2014) and Aidt and Franck (2015) provide supportive econometric evidence on the link between threat of revolution and democratization. Based on the aforementioned contributions, Besley and Persson (2019) model the drivers of democratic reforms as a dynamic interplay between strategic decisions on violence to affect political turnover and democratic values.

A key takeaway from this line of political economy research is that the first cell of change and what matters most is constitutional democracy, which refers to the set of authority patterns included in countries' constitutions (Eckstein and Gurr, 1975, p.41). Central to the distinction

between different authority patterns is the way executives are recruited. Specifically, "executive recruitment involves the ways in which superordinates come to occupy their positions...In current sociological jargon this is a species of 'boundary interchange," a matter of crossing lines between superordinate and subordinate positions" (Eckstein and Gurr 1975).

Moreover, constitutional democracy contains structural characteristics by which chief executives are recruited, namely competitiveness of executive recruitment and openness of executive recruitment. Competitiveness refers to the extent that prevailing modes of advancement give subordinates equal opportunities to become superordinates, whereas openness refers to the extent that all the politically active population has an opportunity, in principle, to attain chief executive position through a regularized process. 
A key characteristic of authority patterns is the extent to which the chief executive ruler must take into account the preferences of others when making decisions. An indispensable ingredient of these processes, therefore, is the existence of executive constraints (decision rules) in constitutions that provide basic criteria under which decisions are considered to have been taken. Another general authority trait of polities is participation. The operational question is the extent to which the political system enables non-elites to influence political elites in regular ways. Competitiveness of participation refers to the extent to which alternative preferences for policy and leadership can be pursued in the political arena.

The above constitutional characteristics are the basis and the prerequisites for all institutional changes to happen. Most notably, political transition to constitutional democracy (as a source of redistribution) implies investing in human capital policies, such as education, health, creativity, and labor force participation (Acemoglu et al., 2019), which reduce risk, reduce uncertainty, reduce transaction costs (Coase, 1992), are conducive to private enterprise (Begović, 2013), and ensure the basis of a healthy system for business development and entrepreneurship (Acemoglu et al., 2014).

From an entrepreneur's viewpoint, democratization usually enhances contract enforceability; reduces expropriation, blackmailing, or a sudden eruption of political instability; protects private enterprise; and protects market competition (Begović, 2013; Acemoglu et al., 2014). ${ }^{3}$ Thus, constitutional democracies and the underlying democratization process limit the negative externalities of business activities and support a healthy system for business development.

Given these characteristics of constitutional democracies, the democratization process

\footnotetext{
${ }^{3}$ We mostly refer to democratization as opposed to the level of democracy because the dynamic changes are those more likely to generate responses in affect the profit-shifting behavior of firms. This is only essential for empirical identification, where we use country fixed effects to absorb all the cross-sectional (time-invariant) country characteristics.
} 
might increase the opportunity and reputation costs of shifting profits abroad. The opportunity costs of profit-shifting especially increase when democratic development leads to reduced country risk for investment, political stability, and enhanced property rights. Within an environment of quickly developing constitutional democracy, firms can reinvest profits and grow quicker in the long run compared to nondemocratic countries or even countries with stable democracies. An additional opportunity cost arises because of the lower cost of borrowing in democratic countries compared to nondemocratic ones, which is the result of lower informational asymmetries in democratic countries (Delis et al., 2019). Thus, firms undergoing a democratic transition might reduce profit-shifting because they experience decreasing costs of credit.

Concerning reputation costs, firms that engage in aggressive profit-shifting take the risk of incurring additional charges. In particular, Klassen et al. (2017), using a survey of 219 tax executives, concludes that half of them work to comply primarily with complex tax laws and avoid disputes with various tax authorities. As democracies are constitutionally established, these disputes might be solved more quickly and efficiently, and thus firms might reduce international profit-shifting to foreign countries, especially to those with weaker and stable democratic basis.

There are also theoretical arguments for a positive relationship between democracy and profit-shifting aggressiveness. Democracies might be associated with higher tax rates (partially to finance the more sophisticated democratic institutions), therefore limiting tax incentives and generating electoral benefits from policing tax avoidance by MNEs (Jensen, 2013). However, anecdotal evidence on corporate tax rates suggests that this is not the case. Part of the reason why corporate tax rates are lower among more democratic countries is that they have a greater ability to assess other types of taxes; for example, current individual tax rate rankings suggest that more democratic countries are more heavily reliant on individual income taxes. Further, by being more open economies, democracies tend to compete for capital and engage in tax competition strategies 
that lower corporate tax rates.

Overall, the theoretical argument that constitutional democratization keeps profits at home seems to outweigh the argument that constitutional democratization increases outbound profitshifting. We thus formulate our first hypothesis as follows:

Hypothesis 1. Constitutional democratization at home leads to less outbound profit-shifting.

\subsection{Democratic Institutions and Tax-Related Profit Shifting}

Constitutional democracy is an institutional umbrella, but its effects on profit-shifting might be stronger if certain institutions are well-developed. ${ }^{4}$ High institutional uncertainty affects the ability of governments to meet their commitments even if governments are benevolent (Brader et al., 2013). It may also mean that politicians find it more efficient to rely on clientelist networks to mobilize support, rather than providing public goods (Keefer, 2007; Keefer \& Vlaicu, 2007). Thus, policymakers, civil society groups, and scholars increasingly agree that good governance and efficient implementation of institutional changes matter for reaping the benefits of democratization (e.g., Dreher et al., 2009). ${ }^{5}$ For example, poor institutional quality even within democratic regimes - corruption, red tape, weak protection of property rights, and ineffective rule of law significantly increase uncertainty and country risk, and they do not provide incentives to realize long-term and risky investments (Olson, 2000).

Prior research shows that democratization improves institutions and better-quality institutions can constrain profit-shifting. Sugathan and George (2015) document how freedom of

\footnotetext{
${ }^{4}$ North (1990) offers the following definition: "Institutions are the rules of the game in a society or, more formally, are the humanly devised constraints that shape human interaction."

${ }^{5}$ This growing consensus emerged from a proliferation of empirical measures of institutional quality, governance, and investment climate, and accompanying research shows the strong development impact of good governance (Mauro, 1995; Hall and Jones, 1999; Robinson et al., 2005).
} 
expression, governmental effectiveness, and political stability affect income shifting. In high-tax countries (the party at loss of tax revenues), the institutions dissuading and limiting negative externalities of business activities are likely to increase the costs of shifting transactions. In particular, they observe that perceptual measures of transparency and public accountability significantly raise the costs of profit shifting activities. Other research has examined how income shifting is affected by features of tax law (Markle 2016), financial accounting quality and comparability (De Simone 2016), intellectual property protection (Griffith et al. 2014), tax reporting requirements (Joshi 2020).

To this end, and besides the main effect of constitutional democratization on profit shifting (over and above any direct effect of institutions) we also consider the institutional channels that transmit this effect. Three are the most important: quality of government, rule of law, and control of corruption. The relevance of these institutional characteristics for firms' profit-shifting decisions comes from their effects on the way firms manage transactions in countries where they pay taxes.

Specifically, quality government regulations provide credible information on government policies and strategies, foster information transparency, and deter profit-shifting. Democracy through better regulatory quality reduces tax inconsistency and can improve tax enforcement efforts (reducing tax audit risk, imposing thin capitalization rules) to constrain outbound income shifting (Beuselinck et al. 2015). Also, democratization encourages countries to adopt regulatory reforms that bring them into line with better governed countries (Mattli and Plumper, 2002) and to join international cooperative organizations that promote regulatory best practices, such as the EU and the OECD (Mansfield and Pevehouse, 2006). Thus, countries adopt the BEPS initiative and use its suggested mechanisms to constrain profit-shifting.

The rule of law secures property rights, as well as enables greater private control and security over firms' earnings. In the absence of a credible rule of law, contracts might not be strictly 
enforceable and firms may fear expropriation. There is typically no reliable contract enforcement unless there is an impartial court system that can call upon the coercive power of the state to require individuals to honor the contracts they have made. Thus, the only societies where individual rights to property and contract are confidently expected to last across generations are the securely democratic societies (Olson, 1993). When legal institutions are stronger, however, the negative relationship between societal trust and tax evasion is less pronounced (Kanagaretnam et al., 2018).

Finally, in the presence of corruption, firms face risks, fear of blackmailing, or sudden instability, which makes doing business problematic. For example, bribes, unlike taxes, involve unpredictable distortion in the discretionary and uncertain use of government power. This results in additional costs to businesses and allocates resources to unproductive activities, which impose an extra burden on firms and the economy (Cieślik and Goczek, 2018). Democratization improves control of corruption (Hill, 2003). Corruption amplifies profit shifting. Multinationals that have an incentive to shift profits will shift more profits with higher corruption in the tax administration. On average, countries with high levels of corruption face lower tax revenue elasticities with respect to tax rates. Therefore, tax rate increases lead to much smaller tax revenue increases in corrupt countries (Bilicka and Seidel, 2020).

Given these theoretical considerations, we suggest that enhancing these institutions reduces the incentives to shift profits abroad. We thus formulate our second hypothesis as follows:

Hypothesis 2. Improvements in regulatory effectiveness, judicial credibility, and control of corruption are key channels through which constitutional democratization affects outbound profitshifting. 


\section{Empirical Model}

\subsection{Estimation of Profit-Shifting by Subsidiary Year}

To study the relationship between democracy and profit-shifting, we first develop a measure of profit-shifting estimated at the subsidiary-year level. Thus far, most of the literature offers aggregate profit-shifting estimates globally or by country (Hines and Rice, 1994; Huizinga and Laeven, 2008; Dharmapala and Riedel, 2013), ${ }^{6}$ whereas De Simone et al. $(2017,2019)$ provide a measure of profit shifting at subsidiary and MNE-year level, respectively, but not at subsidiaryyear level. Our profit-shifting measure follows Delis et al. (2021) and Delis et al. (2022), and extends the empirical models of Hines and Rice (1994) and Huizinga and Laeven (2008). Hines and Rice (1994) examine the shifted income between a parent firm and its subsidiaries considering their countries' tax rate differentials, whereas Huizinga and Laeven (2008) augment this analysis by allowing for tax-rate differentials across countries of all subsidiaries in the same group.

Following Huizinga and Laeven, the baseline empirical model is of the following form ${ }^{7}$ :

$$
E B T_{s t}=a_{1} C T_{s t}+u_{s t}
$$

The outcome variable $E B T_{s t}$ is earnings before taxes (in logs) of the subsidiary $s$ at year $t$. The variable $C T_{s t}$ is the composite tax variable that summarizes all information about subsidiaries' profit-shifting tax-incentives in year $t$; it is defined as:

$$
C T_{s t}=\frac{1}{\left(1-\tau_{s}\right)} \frac{\sum_{k \neq i}^{n}\left(\frac{B_{k}}{1-\tau_{k}}\right)\left(\tau_{s}-\tau_{k}\right)}{\sum_{k=1}^{n}\left(\frac{B_{k}}{1-\tau_{k}}\right)},
$$

where $\tau_{s}$ is the statutory tax rate of the subsidiary country, $\tau_{k}$ is the statutory tax rates of all the affiliated subsidiaries' countries, $B_{k}$ is subsidiary assets (rather than sales, in case sales data are too

\footnotetext{
${ }^{6}$ For an analytical exposition of profit shifting measures in the literature, see Dharmapala (2014).

${ }^{7}$ Our model does not include proxies for capital and labor as Huizinga and Laeven (2008) do. However, we control for these in the second stage of our analysis (see equation 3 ).
} 
distorted by profit-shifting $)^{8}$ used to proxy for multinational activities in different locales, and $u_{s t}$ is the stochastic disturbance. A positive value for $C T$ in equation (1) shows that subsidiary $s$ has tax incentives to shift profits out of its country for tax-related reasons.

We are interested in the negative effect of $C T$ on $E B T$ in equation (1) when $C T$ is positive, (i.e., an increase in $C T$ via an increase in $\tau_{s}$ leads subsidiaries to send more profits abroad and thus reduces domestic EBT). This implies that we disregard cases of positive responses (i.e., the subsidiary does not send profits abroad when tax rates in the host country increase). Also, we do not include observations for which $C T$ is negative and there is a negative effect of $C T$ on $E B T$ in equation (1), even though these observations represent a tax incentive and opportunity to shift income into the subsidiary. We do so, because that is the case for only 73 observations in our sample (if we chose to include them our results remain the same) and our research question is how democracy affects outbound profit-shifting (not inbound for which we require a different theoretical setting).

Given the above, coefficient $a_{1}$ is an aggregate estimate of profit-shifting aggressiveness, essentially representing how much profit subsidiaries send abroad. Our contribution is the estimation of profit-shifting by subsidiary-year, which implies estimating $a_{1, s t}$. The best way to do this is via nonparametric techniques. In these techniques, the data determine the form of the fitted regression lines, which are fully nonlinear and thus do not rely on assumptions regarding the shape of the relationship between the variables.

The underlying model for local regression is $Y_{i t}=\mu\left(x_{i t}\right)+\varepsilon_{i t}$, where $x$ is a predictor variable and $Y$ is the response variable. We estimate the unknown function $\mu(x)$ by fitting a polynomial model within a sliding window (neighborhood of $x$ ). Differently phrased, the estimate

\footnotetext{
${ }^{8}$ We prefer assets, because sales data can be distorted by transfer-pricing policies of MNEs used to exploit specific transfer pricing rules (Behrens et al., 2014). Our results are robust to the use of sales.
} 
of $\mu$ at $x$ uses all observations whose $x_{i t}$ values are closest to $x$, and each point in this neighborhood is weighted according to its distance from $x$. Points close to $x$ have large weights, and points far from $x$ have small weights. No strong assumptions are made about $\mu$ globally, but locally around $x$ we assume that $\mu$ can be well approximated. By using these observation-specific sliding windows, we obtain observation-specific $\hat{a}_{1, s t}$.

Two important issues in the estimation are the choice of the kernel (the weighting function) and the optimal bandwidth (the smaller the bandwidth is, the larger the weight assigned to points between $x$ and $x_{i}$ ). We mainly use an Epanechnikov kernel, but we also experiment with Gaussian, triangle, and biweight kernels. In turn, researchers propose many alternatives for deriving the optimal bandwidth (e.g., Greene, 2018); we choose the one that minimizes the integrated mean squared error of the prediction (cross-validation method). We find that our results are not overly sensitive to bandwidth (unless the choice is far off the one chosen by cross-validation).

A third important issue is that this class of models suffers from the so-called curse of dimensionality when the estimation encounters regions with small density in observations. ${ }^{9}$ To avoid this problem, we impose that sliding windows must have at least 100 observations; we drop the rest of the observations from our analysis (essentially this is equivalent to dropping outliers). ${ }^{10}$ For further details on the construction of our profit-shifting measure, see the Appendix (part A).

We estimate profit-shifting using a sample of 90 countries, where 49,418 subsidiaries reside from 2009 to 2017. The total number of subsidiary-year observations for which we have information to estimate profit-shifting is 254,262 , and the financial variables are in U.S. dollars (current prices). For details on sample construction, see Appendix (part A).

\footnotetext{
${ }^{9}$ This essentially means a small number of observations within the sliding window. As in any parametric regression with a small number of observations, this implies less precise estimates.

${ }^{10}$ We find that increasing the minimum number of observations to 150 or 200 does not affect our results but reduces the number of estimates $\hat{a}_{1, s t}$ (and thus the availability of observations for the rest of our empirical analysis).
} 
Our primary data source is Orbis, which has worldwide coverage of firm-year accounting data, as well as detailed information on firm ownership structures. ${ }^{11}$ For the estimation of profitshifting, we use subsidiaries' earnings before taxes $(E B T)$ and assets $\left(B_{k}\right)$. Moreover, we use the statutory tax rate of subsidiaries' countries $\left(\tau_{s}\right)$ and the statutory tax rates of all the affiliated subsidiaries' countries $\left(\tau_{\mathrm{k}}\right)$, obtained from Ernst \&Young's Worldwide Corporate Tax Guide. ${ }^{12}$ For the theoretical justification on using statutory (as opposed to effective) corporate tax rates, see Deveraux and Mafini (2007) and Huizinga and Laeven (2008).

As discussed, tax-related profit-shifting occurs when $\widehat{a}_{1, s t}$ is negative and $C T$ is positive. This the case for 80,939 observations, corresponding to 18,966 subsidiaries and 72 countries. However, due to several missing data, especially for subsidiary and MNEs characteristics, our main sample is smaller than the sample with profit-shifting estimates; it includes 27,103 observations for 6,590 subsidiaries in 57 countries. In Appendix Table B1, we report average profit-shifting estimates by country and list the countries in our analysis. We find that subsidiaries in United States shift more profit abroad, followed by big countries such as Japan and India, which have high corporate tax rates. We observe the lowest profit-shifting in African and Eastern European countries, which typically have low corporate tax rates. We report average statutory tax rates by country in Appendix Table B2.

\subsection{Democracy and Profit-Shifting}

Given the subsidiary-year estimates of profit-shifting, we examine the relation:

\footnotetext{
${ }^{11}$ Orbis data has the drawback that firms' ownership structure is available for the last reported date only. Therefore, there may be some concerns about misclassification bias as the ownership structure may change during the sample period. However, considering that this bias drives our estimations toward zero (Budd et al., 2005), if anything we underestimate profit-shifting.

${ }^{12}$ https://www.ey.com/gl/en/services/tax/worldwide-corporate-tax-guide---country-list.
} 


$$
\begin{aligned}
& \text { Profit shifting } \text { st }_{s t}=b^{\prime}+b_{1} \text { Democracy }_{c t}+b_{2} C_{c s t}+b_{3} C_{c m t}+b_{4} F_{s t} \\
& +b_{5} F_{m t}+\varepsilon_{f c t} .
\end{aligned}
$$

where, Profit-shifting is our measure of profit-shifting obtained in the previous section for subsidiary $s$ in year $t ; b^{\prime}$ indicates a full set of subsidiary, industry, country, and year fixed effects; Democracy is an index of the quality of democratic institutions in the subsidiary's country; $C$ and $F$ are sets of country and firm controls at the subsidiary $(s)$ and MNE $(m)$ levels, and $\varepsilon$ is the stochastic disturbance. We use control variables (country and firm) both at the multinational enterprise group level and at the subsidiary level, as both might affect the profit-shifting decisions. The coefficient of our interest is $b_{1}$, which captures the effect of democracy on subsidiaries' profitshifting to other countries for tax-related purposes. To facilitate our interpretation of how democracy affects profit-shifting in our regression analysis, we multiply our profit-shifting index by -1 so that higher values of Profit-shifting actually reflect more aggressive profit-shifting. ${ }^{13}$

Table 1 provides definitions and data sources for the variables in our empirical analysis. The literature measures democracy using several indices of the quality of political institutions, and such measures tend to be either the result of research by political scientists (e.g., the Polity IV project) or are calculated on the basis of surveys of representative individuals (e.g., the Freedom House dataset).

Our preferred measure of democracy (Democracy polity) is the one from the Polity IV Project (termed "Democ" in that database) ${ }^{14}$ This is a country-year index that ranges from 0 (lack

\footnotetext{
${ }^{13}$ An alternative to estimating equations (1) and (3) separately would be a reduced-form model that includes an interaction term of the composite tax variable (CT) and a democracy index. However, that would be only a global estimate and not a subsidiary-year measure of profit-shifting. Further, as Huizinga and Laeven also suggest, both the top statutory tax rate used to calculate CT, and their variable CT might be endogenous. The problem in our setting is that the democracy index might also be endogenous in specifications with subsidiary profits as the outcome variable (i.e., the HL model). Finding instruments for numerous (and different) variables is not fruitful and implies the potential for significant bias in our estimates.

${ }^{14}$ https://www.systemicpeace.org/polityproject.html.
} 
of institutional democracy) to 10 (institutional democracy of the highest quality). According to the Polity IV Project: Dataset Users' Manual v2018, "Democracy is conceived as three essential, interdependent elements. One is the presence of institutions and procedures through which citizens can express effective preferences about alternative policies and leaders. Second is the existence of institutionalized constraints on the exercise of power by the executive. Third is the guarantee of civil liberties to all citizens in their daily lives and in acts of political participation. Other aspects of plural democracy, such as the rule of law, systems of checks and balances, freedom of the press, and so on are means to, or specific manifestations of, these general principles."

[Please insert Table 1 about here]

An advantage of this measure is that it is institution-based and not perception-based, which allows examining the effect of institutionalized democracy, purified from perceptions that are usually endogenous to political and economic outcomes. Furthermore, based on its definition, Democracy polity is separated into four sub-indices (thoroughly defined in Table 1). These reflect the presence of institutions and procedures through which citizens can express effective preferences about alternative policies and leaders (Competitiveness of executive recruitment); the existence of equal opportunities to advance in chief executive positions through a regularized process (Openness of executive recruitment); the existence of institutionalized constraints on the exercise of power by executives (Executive constraints); and the guarantee of civil liberties to all citizens in their daily lives and in acts of political participation (Competitiveness of participation).

In robustness tests, we use two more democracy measures. The Freedom House index (Democracy $F H$ ), is a perception-based measure that ranges from 0 (autocratic country) to 10 (free democratic country) and considers civil and social liberties, the rule of law, and freedom from corruption. Despite its disadvantages compared to Democracy polity, examining perception-based democracy dimensions is important because profit-shifting decisions might also be based on 
perceptions as reflected in civil liberties. Nevertheless, the two indicators have a $96 \%$ correlation in our sample (see Appendix Table B3).

Moreover, we use the simpler Boix, Miller, and Rosato (2013) measure (Democracy BMR), an institution-based dichotomous variable that goes from 0 to 1 when countries choose their political leaders through fair and free elections and satisfy a threshold value of suffrage. ${ }^{15}$ This measure is also highly correlated with Democracy polity (87\%) and Democracy FH (85\%).

We also consider quality of governance indicators. We mostly resort to information from the World Bank's Worldwide Governance Indicators (WGI) database. These governance indicators are from the aggregation of 340 variables from different sources and grouped into six different dimensions. We use three dimensions most relevant to business practices: (i) regulatory quality; (ii) rule of law; and (iii) control of corruption.

These three aspects of governance quality may influence how democracy affects subsidiaries' profit-shifting decisions: regulatory quality (i.e., policies and regulations that enable and promote private sector development - regulatory burden, tax distortions, business freedom, investment freedom, financial freedom), rule of law (i.e., property rights, government integrity, judicial effectiveness), and control of corruption (i.e., the extent to which public power is exercised for private gain, including both petty and grand forms of corruption, as well as "capture" of the state by elites and private interests). As indicated in Appendix Table B4, we also consider variables from the Fraser Institute and the Heritage Foundation.

Despite the fact that Democracy polity is predetermined, identifying democracy's causal effect on profit-shifting is an empirical challenge mostly because any democracy index might capture unobserved country characteristics affecting profit-shifting, thus leading to omitted-

\footnotetext{
${ }^{15}$ https://qog.pol.gu.se/data
} 
variable bias. ${ }^{16}$ We proceed with several remedies against this bias. First, to reduce the possibility that the coefficient of democracy captures the effect of other country-year characteristics, in control set $C$ we include a large number of relevant controls (altogether more than 50 variables), all of which are listed in Appendix Table B4. The most important ones are a country's economic performance and market size, proxied by output per capita, annual output growth rate, and population, which we use in our baseline specifications.

Further, following the literature (Huizinga and Laeven, 2008; Dharmapala and Riedel, 2013; De Simone et al., 2017), set $F$ includes controls for firm size measured by the log of total assets, tangibility (the ratio of fixed assets to total assets), leverage (the ratio of total liabilities to total assets), and cost of employees (the log of cost of employees; available only for MNEs).

Second, we include country, industry, subsidiary, and year fixed effects. The country fixed effects control for time-invariant characteristics of a subsidiary country, which implies identification from changes in democracy; this is important, as changes in democracy are unlikely to take place simultaneously with other important events. Even if this the case, democratic developments usually overshadow the effect of other institutional changes because democracy is the general umbrella of institutions (Delis et al., 2019). Industry fixed effects (at the two-digit level) control for time-invariant, industry-specific characteristics that might affect profit-shifting. The subsidiary fixed effects control for time-invariant subsidiary characteristics and render the country and industry fixed effects redundant. The year fixed-effects control for annual unobserved shocks common to all subsidiaries in our sample.

Given all relevant control variables and fixed effects, omitted-variable bias is only possible

\footnotetext{
${ }^{16}$ One potential concern is that profit-shifting is an estimate and thus measured with error. However, in the estimation of equation (3), this is not as important, because profit-shifting is the outcome variable and measurement error in the dependent variable does not yield inconsistent OLS estimates (e.g., Wooldridge, 2015).
} 
in the presence of unobserved time-variant characteristics, which correlate with a change in both our profit-shifting and democracy indexes. To insulate our analysis further from omitted-variable bias, we use an instrumental variables (IV) approach. To this end, we closely follow Acemoglu et al. (2019) and Delis et al. (2019). Our instrument is the 10-year lag of regional democratization in the subsidiary country. Our exclusion restriction states that regional democratization 10 years ago only affects profit-shifting in the current period via its effect on democracy in the current period. ${ }^{17}$ Intuitively, this should hold: in their profit-shifting decisions, subsidiaries consider the current quality of democratic institutions in their countries and not the quality of democratic institutions in the region - especially not the regional quality 10 years ago. Further, Acemoglu's regional democratization instrument is constructed in a way that captures all the past economic and democratic trends ${ }^{18}$.

\subsection{Summary Statistics}

Table 2 reports summary statistics for the variables in our analysis, and pairwise correlations are in Table B5 in the Appendix. Most countries in our sample demonstrate democratic principles (Appendix Table B6), but these values are skewed because most subsidiaries are in more democratic countries. A slightly different picture emerges when one considers country-year summary statistics (Appendix Table B7), drawing a more realistic picture of the average Democracy polity worldwide. Further, as Appendix Table B6 shows, there are 11 countries where

\footnotetext{
${ }^{17}$ In addition to mitigating omitted-variable bias, the instrumental-variable estimation mitigates any possible measurement error in democracy and reverse causality problems (which are more unlikely).

${ }^{18}$ Their approach defines the regional influence to democratize a country. For each country, they examine whether the country was a democracy or nondemocracy in 1960, and the geographic region in which the country lies. These regions are Africa, East Asia and the Pacific, Eastern Europe and Central Asia, Western Europe and other developed countries, Latin America and the Caribbean, the Middle East and the North of Africa, and South Asia. They assume that democracy in a country is influenced by democracy in the set of countries in the same region that also share a similar political history.
} 
democracy changes 15 times, of which half move to higher democracy levels and half move to lower democracy levels.

The sample for which all important variables are nonmissing is smaller compared to the sample for which we obtain positive profit-shifting estimates. It includes 27,103 observations, corresponding to 6,590 subsidiaries in 57 countries. Our profit-shifting index in this sample has an average of 0.81 and a standard deviation of 0.58 , ranging between 0 and 3.12 .

The correlation coefficient between Profit-shifting and Democracy polity is -0.079 , statistically significant at conventional levels (Appendix Table B5). Figure 1 shows the development of Democracy polity and Democracy FH (left axis) and Profit-shifting (right axis) over time. There is an approximately $58 \%$ increase in profit-shifting during our sample period, whereas democracy decreases by $3 \%$ under both indices.

[Please insert Table 2 \& Figure 1 about here]

Regarding the quality of specific institutions, in figure 2 the three graphs plot corruption, the rule of law, and regulatory quality against Democracy polity over time. Evidently, there is a positive correlation that is not as extremely high (see also the correlation coefficients in Appendix Table B3). Thus, the quality of governance characteristics has some differential information vis-àvis that of democratic institutions.

\section{Empirical Results}

\subsection{Democracy and Profit-Shifting: Baseline Results}

Table 3 reports OLS estimates from the estimation of equation (3). All specifications include our baseline controls and differ on the fixed effects. The first column includes country fixed effects; the second adds year fixed effects; the third adds industry fixed effects; and the fourth adds subsidiary fixed effects (instead of country and industry fixed effects). We double-cluster the 
standard errors by subsidiary and MNE country to reduce the effect of correlated errors within these clusters.

The coefficients of Democracy polity are negative and statistically significant in all specifications at conventional levels, implying that increasing (decreasing) democracy decreases (increases) profit-shifting. If we focus on the most restrictive specification 4, which inter alia includes for subsidiary fixed effects, a one-unit increase in democracy in the subsidiary country decreases profit-shifting to other countries by 0.12 points. For the country with mean profitshifting, this increase in Democracy polity implies a decrease in profit-shifting by approximately $15 \%$ (obtained from $0.12 / 0.81$ ). The equivalent effect from a one-standard-deviation increase in Democracy polity (equal to 1.63 in our sample) is 0.196 points or $24 \%$. Thus, in the OLS models, democracy has a negative and economically significant impact on profit shifting.

[Please insert Table 3 about here]

Table 4 presents evidence based on alternative indices of democracy. Specifications 1 to 4 report estimates of the perception-based Democracy $F H$, and specifications 5 to 8 report estimates of the institutional-based Democracy BMR. In general, the results are economically even more potent than those in Table 3. Based on specification 4, a one-standard-deviation increase in Democracy $F H$ (equal to 1.28) reduces profit-shifting by 0.28 points. Further, moving from 0 to 1 in Democracy BMR lowers profit-shifting by 0.33 points, an economically substantial effect given the mean Profit-shifting of 0.76 in the sample of 17,217 observations (for which we have information on Democracy BMR).

[Please insert Table 4 about here]

Our most important results are those from our IV model (two-stage least squares), which we report in Table 5. The coefficients on Regional democratization (our IV) in the first stage are always statistically significant at the $1 \%$ level, rejecting any issues of weak instrumentation. The 
second-stage results are qualitatively similar to those in Table 3, and all previous findings hold. The impact of democracy is somewhat more potent, ranging from approximately 0.14 (column 2) to 0.19 (column 4) points. A one-standard-deviation increase in Democracy polity (equal to 1.59 in this sample) reduces profit-shifting to other countries by approximately $37 \%$. Thus, if anything, the economic significance of our OLS results are conservative. Given that there is a statistically significant difference in the coefficient estimates between the OLS and the IV models, we use the IV model in the rest of the robustness tests. ${ }^{19} \mathrm{We}$ also replicate our analysis removing observations related to worldwide tax systems (Markle, 2016); the results do not vary significantly. By removing them, we also drop observations for US subsidiaries, in case their Orbis unconsolidated data are not as accurate.

\section{[Please insert Table 5 about here]}

Thus far, we show that the subsidiary country's current democracy level matters in firms' decisions to shift profits abroad. However, before shifting profits to another country, firms may consider the longer-term democratic conditions of their countries. We consider this possibility by including annual lags of Democracy polity in our IV model and report the estimates in Table 6. Controlling for different numbers of lags in specifications 2 to 5 , we find that the first two lags have explanatory power for firms' profit-shifting, and the contemporaneous Democracy polity retains its significance. Obviously, a country's early democratic history increases the information set of firms in their decisions to shift (or not shift) profits elsewhere.

[Please insert Table 6 about here]

We use an additional list of more than 50 control variables in various robustness tests. The variables reflect institutional, cultural, geographic, demographic, and economic characteristics of

\footnotetext{
19 Table B8 in the Appendix reports IV estimates of alternative democracy measure(s) analogous to Table 4. The estimates of Democracy FH are very close to those in Table 4, ranging from 0.19 to 0.26 .
} 
the subsidiary and MNE countries. We list these variables and their sources in Appendix Table B4. Many of these variables are multicollinear (either among themselves or with GDP per capita) and thus we cannot simultaneously include them in the same regression model. We find that our estimates are robust to including these additional variables.

Finally, we show that our results hold in many other robustness tests. In Table B9, we provide some assurance that there is no single country or democratization event that is driving the results. We drop all countries, where democracy changes, with less than 10 observations. We present these estimates against our baseline IV results, to ensure that changing countries with few observations are not driving a global inference. In Table B10, we address outliers by winsorizing our data at levels $1 \%$ and $99 \%$. We replicate our four most restrictive specifications (OLS for the first two columns and IV for the last two). Our results do not vary significantly.

\subsection{Components of Democracy and Profit-Shifting}

Next, we delve deeper into examining what component of our democracy index has the largest effect on profit-shifting. Openness of executive recruitment has a very small number of changes over time, and thus it drops out when using country fixed effects. Accordingly, we only consider the effect of the other three Democracy polity components and report the results in Table 7 . We consider the effects in different specifications because these variables are highly correlated (we provide the correlation matrix in Appendix Table B3). All three variables are statistically significant at the $1 \%$ level.

The effects of one-standard-deviation increases are 0.33 points (or 41\%) for Competitiveness of participation, 0.34 points (or 42\%) for Competitiveness of executive recruitment, and 0.28 points (or 35\%) for Executive constraints. This is in line with the premise that having established free elections under competitiveness of participation, the other key element 
of democratic conditions is the guarantee of civil liberties to all citizens in their daily lives and in acts of political participation. Given that this is the more "qualitative" democratic characteristic of Democracy polity, it is also interesting to examine how the purely qualitative components of Democracy $F H$ affect profit-shifting.

[Please insert Table 7 about here]

We report these results in Table 8 . Consistent with the results in Table 7, we find that all the Democracy FH components, reflecting various forms of civil and political liberties, strongly explain profit-shifting. Economically, the largest effects from a one-standard-deviation increase come from personal autonomy, individual rights, and the rule of law. ${ }^{20}$ Overall, these findings show that firms' profit-shifting behavior is considerably affected by the quality of property rights and business freedom, citizens' ability to make free political choices, and the quality of the judicial system as a means to protect these liberties.

[Please insert Table 8 about here]

\subsection{What Institutions are More Conductive to Less Profit-Shifting?}

Our analysis on the components of Democracy polity and Democracy FH already suggests that both constitutional and perception-based indices are important in explaining profit-shifting. An important goal of our empirical analysis is to pinpoint further the key channels through which democracy shapes profit-shifting. To study channels formally, we need to examine which of the institutional components of democracy affect profit-shifting. We include the general democracy indicators in the same model, but they have less significant effects (so the components capture that part of their effect). Unfortunately, Democracy polity and Democracy $F H$ have very high

\footnotetext{
${ }^{20}$ Note that the positive effect of political rights is not counterintuitive, because this variable takes higher values for lower levels of freedom.
} 
correlations with their components, so that the results have the usual multicollinearity symptoms. Our remedy is to include the WGI indices, which have lower correlations. In that respect, we also bring in information from a different set of institutional characteristics that are not very highly correlated with our democracy indicators and thus bring in somewhat different information.

Table 9, columns 2 to 4, report the relevant IV estimates against our baseline results, which we replicate in column 1 for convenience. We observe reductions in the coefficient estimates on Democracy polity, which are as large as the importance of the effect of the governance variables. Specifically, Control of corruption in column 2 is statistically insignificant, and this has a very small effect on the coefficient of Democracy polity compared to the baseline.

In contrast, the effect of Rule of law (column 3) is negative and highly significant, showing that firms in countries with better protections of property rights, government integrity, and judicial effectiveness are reluctant to move their profits abroad (despite the potential of paying higher taxes). Given the large effect of Rule of law, the coefficient on Democracy polity in column 3 loses approximately $15 \%$ of its power compared to our baseline specification. Together, these findings show that rule of law is an important channel through which democracy affects profit-shifting.

Regulatory quality is also an important channel through which democracy affects profitshifting. This variable enters specification 4 of Table 9 with a negative and highly significant coefficient, and it lowers the impact of Democracy polity compared to our baseline specification by approximately $8 \%$. This finding shows that firms in countries with a significant capacity for national administrators to design and implement quality regulations and policies are also reluctant to shift profits abroad, despite the potentially lower tax burden.

[Please insert Table 9 about here]

Admittedly, this analysis is rougher in terms of identifying causal effects because the governance variables might also be endogenous when entering the profit-shifting equations. 
However, the fact that these variables are essentially components of democracy and that their addition lowers the coefficient on Democracy suggest that this analysis is fruitful even as a direction for future research.

\section{Conclusion}

In a globalized world, firms face competitive pressures to shift profits from high-tax countries to low-tax countries. The mobility of global businesses and their decisions to pay taxes abroad increase the distributional burden of the tax system among domestic economies, shrink government fiscal budgets, and contract government welfare spending.

Using a global sample of MNEs and their subsidiaries, this paper examines the role of constitutional democracy and institutions on profit-shifting. To this end, we construct a subsidiaryyear measure of profit-shifting, which we use as the outcome variable in our main empirical analysis.

We provide robust evidence that democracy has a negative effect on profit-shifting, implying that increasing democratic institutions in subsidiary countries lowers profit-shifting to other countries. Our baseline results suggest that an increase of one standard deviation in our democracy index reduces profit-shifting by approximately $37 \%$. This estimate is robust to an extensive series of sensitivity tests, including different measures of democracy. We also find that high-quality policy-making and the government's ability to protect property rights and enforce contracts are two key channels increasing democracy's effectiveness in keeping subsidiaries' profits home.

Our results suggest that authorities benefit from taking a closer look at how democracy affects firms' profit-shifting decisions. Our findings point to the need for institutional reforms that 
improve government regulatory quality and the effectiveness of the rule of law as de facto policies in deterring business and profit-shifting. As the OECD's BEPS and related projects move forward to fulfill their objectives of increased transparency and tax fairness, we provide evidence that focusing on the quality of institutions that relate to profit-shifting plays an important role in the implementation of this initiative. 


\section{References}

Acemoglu, D., and J.A. Robinson, 2000. Why Did the West Extend the Franchise? Democracy, Inequality, and Growth in Historical Perspective. Quarterly Journal of Economics 115 (4), 1167-99.

Acemoglu, D., and J.A. Robinson, 2006. Economic Origins of Dictatorship and Democracy. Cambridge University Press, New York.

Acemoglu, D., F.A. Gallego, and J.A. Robinson, 2014. Institutions, human capital, and development. Annual Review of Economics 6, 875-912.

Acemoglu, D., S. Naidu, P. Restrepo, and J.A. Robinson, 2013. Democracy, redistribution and inequality. NBER Working Paper No. 19746.

Acemoglu, D., S. Naidu, P. Restrepo, and J.A. Robinson, 2019. Democracy does cause growth. Journal of Political Economy 127, 47-100.

Aidt, T.S., and P.S. Jensen, 2014. Workers of the World, Unite! Franchise Extensions and the Threat of Revolution in Europe, 1820-1938. European Economic Review 72, 52-75.

Aidt, T.S., and R. Franck, 2015. Democratization Under the Threat of Revolution: Evidence From the Great Reform Act of 1832. Econometrica 83 (2), 505-47.

Barro, R.J., 1996. Democracy and growth. Journal of Economic Growth 1, 1-27.

Begović, B., 2013. How democracy influences growth. Center for International Private Enterprise, Washington D.C.

Behrens, K., S. Peralt, and P.M. Picard, 2014. Transfer pricing rules, OECD guidelines, and market distortions. Journal of Public Economic Theory 16 (4), 650-680.

Besley, T., and T. Persson, 2019. Democratic Values and Institutions. American Economic Review 1(1), 59-76.

Beuselinck, C., M. Deloof, and A. Vanstraelen, 2015. Cross-Jurisdictional Income Shifting and Tax Enforcement: Evidence from Public versus Private Multinationals. Review of Accounting Studies 20, 710-746.

Bilicka, K. and A. Seidel, 2020. Profit Shifting and Corruption. International Tax and Public Finance 27, 1051-1080.

Boix, C., M.K. Miller, and S. Rosato, 2013. A complete data set of political regimes, 1800-2007. Comparative Political Studies 46, 1523-1554. 
Brader, T., J.A. Tucker, and D. Duell, 2013. Which parties can lead opinion? Experimental evidence on partisan cue taking in multiparty democracies. Comparative Political Studies 46, $1485-1517$.

Budd, J.W., J. Konings, and M.J. Slaughter, 2005. Wages and international rent sharing in multinational firms. The Review of Economics and Statistics 87, 73-84.

Cieślik A., and Ł. Goczek, 2018. Control of corruption, international investment, and economic growth - Evidence from panel data. World Development 103, 323-335.

Clausing, K.A., 2009. Multinational firm tax avoidance and tax policy. National Tax Journal 62, 703-725.

Clausing, K.A., 2016. The effect of profit shifting on the corporate tax base in the United States and beyond. National Tax Journal 69, 905-934.

Coase, R.H., 1992. Contracts and the activities of firms. Journal of Law and Economics 34, 451452.

De Simone, L., 2016. Does a common set of accounting standards affect tax-motivated income shifting for multinational firms? Journal of Accounting and Economics 61, 135-165.

De Simone, L., K.J. Klassen, and J.K. Seidman, 2017. Unprofitable affiliates and income shifting behavior. The Accounting Review 92, 113-136.

De Simone, L., L.F. Mills, and B. Stomberg, 2019. Using IRS data to identify income shifting to foreign affiliates. Review of Accounting Studies 24, 694-730.

Delis, F., M. Delis, P. Karavitis, and K. Klassen, 2021. Corporate Governance and Profit Shifting: The Role of the Audit Committee. Forthcoming, European Accounting Review.

Delis, F., M. Delis, L. Laeven, and S. Ongena, 2022. Global Evidence on Profit Shifting: The Role of Intangible Assets. London, Centre for Economic Policy Research.

Delis, M., I. Hasan, and S. Ongena, 2019. Democracy and credit. Journal of Financial Economics, Available online 18 October 2019.

Desai, M.A., and D. Dharmapala, 2009. Corporate tax avoidance and firm value. The Review of Economics and Statistics, 91(3), 537-546.

Devereux, M.P., and G. Maffini, 2007. The impact of taxation on the location of capital, firms and profit: a survey of empirical evidence. Oxford University Centre for Business Taxation Working Paper Series, WP 07/02, Said Business School, Oxford. 
Dharmapala, D. and N. Riedel, 2013. Earnings shocks and tax-motivated income-shifting: Evidence from European multinational. Journal of Public Economics 97, 95-107.

Dharmapala, D., 2014. What do we know about base erosion and profit shifting? A review of the empirical literature. Fiscal Studies 35, 421-448.

Dreher, A., C. Kotsogiannis, and S. McCorriston, 2009. How do institutions affect corruption and the shadow economy? International Tax and Public Finance 16(6), 773-796.

Dyreng, S. and K. Markle, 2016. The effect of financial constraints on income shifting by U.S. multinationals. The Accounting Review 91, 1601-1627.

Eckstein, H. and T. Gurr, 1975. Patterns of authority: A structural basis for political inquiry. New York: Wiley-Interscience.

Gerring, J., P. Bond, W. Barndt, and C. Moreno, 2005. Democracy and economic growth: A historical perspective. World Politics 57, 323-364.

Gravelle, J.G., 2009. Tax havens: International tax avoidance and evasion. National Tax Journal $62,727-753$.

Greene, W.H, 2018. Econometric Analysis, 8th Edition. Pearson.

Griffith, R., H. Miller, and M. O'Connell, 2014. Ownership of Intellectual Property and Corporate Taxation. Journal of Public Economics 112, 12-23.

Guvenen, F., G. Kambourov, B. Kuruscu, S. Ocampo-Diaz, and D. Chen, 2019. Use it or lose it: Efficiency gains from wealth taxation. NBER Working Paper No. 26284.

Hall, R.E., and C.I. Jones, 1999. Why do some countries produce so much more output per worker than others? The Quarterly Journal of Economics 114, 83-116.

Helliwell, J., 1994. Empirical linkages between democracy and economic growth. British Journal of Political Science 24, 225-248.

Hill, K.Q., 2003. Democratization and Corruption: Systematic Evidence from the American States. American Politics Research 31(6), 613-631.

Hines, J. and E. Rice, 1994. Fiscal paradise: Foreign tax havens and American business. The Quarterly Journal of Economics 109, 149-182.

Huizinga, H. and L. Laeven, 2008. International profit shifting within multinationals: A multicountry perspective. Journal of Public Economics 92, 1164-1182.

Jensen, N.M., 2013. Domestic institutions and the taxing of multinational corporations. International Studies Quarterly 57(3), 440-448. 
Joshi, P., 2020. Does Private Country-by-Country Reporting Deter Tax Avoidance and Income Shifting? Evidence from BEPS Action Item 13. Journal of Accounting Research 58(2), 333381.

Kanagaretnam, K., J. Lee, C.Y. Lim, and G. Lobo, 2018. Societal trust and corporate tax avoidance. Review of Accounting Studies 23, 1588-1628.

Keefer, P., 2007. Clientelism, Credibility, and the Policy Choices of Young Democracies. American Journal of Political Science 51, 804-821.

Keefer, P. and R. Vlaicu., 2007. Democracy, Credibility, and Clientelism. Journal of Law, Economics, and Organization 24(2), 371-406.

Klassen, K., M. Lang, and M. Wolfson, 1993. Geographic income shifting by multinational corporations in response to tax rate changes. Journal of Accounting Research 31, 141-173.

Klassen, K.J., P. Lisowsky, and D. Mescall, 2017. Transfer pricing: Strategies, practices and tax minimization. Contemporary Accounting Research 34, 455-493.

Mansfield, E. and J. Pevehouse, 2006. Democratization and International Organizations. International Organization 60, 137-167.

Markle, K., 2016. A comparison of the tax-motivated income shifting of multinationals in territorial and worldwide countries. Contemporary Accounting Research 33, 7-43.

Mattli, W. and T. Plumper, 2002. The Demand-Side Politics of EU Enlargement: Democracy and the Application for EU Membership. Journal of European Public Policy 9(4), 550-574.

Mauro, P., 1995. Corruption and growth. The Quarterly Journal of Economics 110, 681-712.

North, D., 1990. Institutions, Institutional Change and Economic Performance. Cambridge: Cambridge University Press.

OECD, 2013. Action Plan on Base Erosion and Profit Shifting. Paris: OECD.

OECD, 2013. Addressing Base Erosion and Profit Shifting. Paris: OECD.

Olson, M., 1993. Dictatorship, Democracy, and Development. The American Political Science Review 87(3), 567-576.

Olson, M., 2000. Power and Prosperity: Outgrowing Communist and Capitalist Dictatorships. Oxford University Press, Oxford, UK.

Papaioannou, E., and G. Siourounis, 2008. Democratisation and growth. Economic Journal 118, 1520- 1551. 
Persson, T., and G. Tabellini, 2009. Democratic capital: The nexus of political and economic change. American Economic Journal: Macroeconomics 1, 88-126.

Polity IV Project, 2019. Political regime characteristics and transitions, 1800-2018: Dataset Users' Manual. Center for Systemic Peace, Vienna, VA, USA.

Przeworski, A., and F. Limongi, 1993. Political regimes and economic growth. Journal of Economic Perspectives 7, 51-69.

Robinson, J., D. Acemoglu, and S. Johnson, 2005. Institutions as a fundamental cause of long-run growth, Aghion, P. and Durlauf, S.N. (Eds.) Handbook of Economic Growth, 2005, 1A, 386472.

Rodrik, D., and R. Wacziarg, 2005. Do democratic transitions produce bad economic outcomes? American Economic Review 95, 50-55.

Sirowy, L., and A. Inkeles, 1990. The effects of democracy on economic growth and inequality: A review. Studies In Comparative International Development 25, 126-157.

Sugathan, A., and R. George, 2015. The influence of governance infrastructure and corporate governance on profit shifting. Journal of International Business Studies 46, 886-916.

Tavares, J., and R. Wacziarg, 2001. How democracy affects growth. European Economic Review 45, 1341-1378.

Tørsløv, T.R., L.S. Wier, and G. Zucman, 2018. The missing profits of nations. NBER Working Paper No. 24701.

Weichenrieder, A.J., 2009. Profit shifting in the EU: Evidence from Germany. International Tax and Public Finance 16, 281-297.

Wooldridge, J.M., 2015. Econometric analysis of cross-section and panel data. Cambridge, MA: MIT.

Zucman, G., 2014. Taxing across borders: Tracking personal wealth and corporate profits. Journal of Economic Perspectives 28, 121-48. 
Table 1. Variables Definitions and Sources

\begin{tabular}{llc}
\hline \hline Variable & \multicolumn{1}{c}{ Definition } & Source \\
\hline Dependent variable & & \\
Profit-shifting & $\begin{array}{l}\text { Estimates } \hat{a}_{1, s t} \text { from the estimation of equation (1) using a fully } \\
\text { nonparametric local linear regression. We use an Epanechnikov kernel and }\end{array}$ & Own \\
& estimation & based on \\
& Orbis and \\
& EY Tax \\
& Guide \\
\hline
\end{tabular}

Explanatory variables: Firm characteristics

$\begin{array}{lll}\text { EBT } & \text { Subsidiary's earnings before taxes }(\log ) . & \text { Orbis }\end{array}$

Firm size

Tangibility

Leverage

Subsidiary's and MNE's total assets (log).

Orbis

Subsidiary's and MNE's tangibility, defined as fixed assets/total assets. Orbis

Cost of employees

Subsidiary's and MNE's leverage, defined total liabilities/ total assets.

Orbis

MNE's cost of employees (log).

Orbis

Explanatory variables: Country characteristics

Democracy polity

Democracy FH

Democracy BMR

Competitiveness of executive recruitment

Openness of executive recruitment

Executive constraints

Competitiveness of participation

Personal autonomy and individual rights
Ranges from 0 to 10 , with 0 indicating no institutional democracy and 10 indicating a maximum level of institutional democracy.

A perception-based measure that ranges from 0 (autocratic country) to 10 (free democratic country).

Dummy variable equal to 1 if country is a democracy, zero otherwise.

Refers to the extent that prevailing modes of advancement give subordinates equal opportunities to become superordinates.

Recruitment of the chief executive is "open" to the extent that all the politically active population has an opportunity, in principle, to attain the position through a regularized process.

Refers to the extent of institutionalized constraints on the decision-making powers of chief executives, whether individuals or collectivities.

Refers to the extent to which alternative preferences for policy and leadership can be pursued in the political arena.

Evaluates the extent of state control over travel, choice of residence, employment or institution of higher education; the right of citizens to own property and establish private businesses; the private business' freedom from undue influence by government officials, security forces, political parties or organized crime; gender equality, freedom of choice of marriage partners and size of family; equality of opportunity and absence of economic exploitation. Countries are graded between 0 (worst) and 16 (best).
Polity IV

Project

(2018)

Freedom

House

Boix,

Miller, and

Rosato

(2013)

Polity IV

Project

(2018)

Polity IV

Project

(2018)

Polity IV

Project

(2018)

Polity IV

Project

(2018)

Freedom

House 
Political pluralism and participation

Political rights

Rule of law FH

GDP per capita

GDP growth

Population

Control of corruption

Regulatory quality

Rule of law
Encompasses an examination of the right of the people to organize freely in political parties; the existence of an opposition with a realistic possibility to increase its support; the ability of the people to make political choices free from domination by the military, totalitarian parties, or other powerful groups; and the existence of full political rights for all minorities. Countries are graded between 0 (worst) and 16 (best).

Political rights enable people to participate freely in the political process, including the right to vote freely for distinct alternatives in legitimate elections, compete for public office, join political parties and organizations, and elect representatives who have a decisive impact on public policies and are accountable to the electorate. The specific list of rights considered varies over the years. Countries are graded between 1 (most free) and 7 (least free).

Measures the independence of the judiciary; the extent to which rule of law prevails in civil and criminal matters; the existence of direct civil control over the police; the protection from political terror, unjustified imprisonment, exile, and torture; absence of war and insurgencies; and the extent to which laws, policies, and practices guarantee equal treatment of various segments of the population. Countries are graded between 0 (worst) and 16 (best).

GDP per capita in constant prices.

Annual GDP growth rate.

Country's population.

Captures perceptions of the extent to which public power is exercised for private gain, including both petty and grand forms of corruption, as well as "capture" of the state by elites and private interests.

Captures perceptions of the ability of the government to formulate and implement sound policies and regulations that permit and promote privatesector development.

Captures perceptions of the extent to which agents have confidence in and abide by the rules of society, and in particular the quality of contract enforcement, property rights, the police, and the courts, as well as the likelihood of crime and violence.
Freedom House

Freedom House

Freedom House

WDI

WDI

WDI

Worldwide

Governance

Indicators

Worldwide Governance Indicators

Worldwide Governance Indicators

\section{Explanatory variables: Firm and country characteristics}

Composite tax variable Summarizes all information about subsidiaries' profit-shifting tax- Huizinga and incentives in a given year.

Instrumental variables

Regional democratization

Regional waves of democratization and reversals in democracy, excluding information in a subsidiary's country.

Acemoglu 
Table 2. Summary Statistics (57 countries, period: 2009-2017)

The table reports the number of observations as well as the mean, standard deviation, minimum, maximum, and median of the main variables used in the empirical analysis. The variables are defined in Table 1.

\begin{tabular}{|c|c|c|c|c|c|c|}
\hline & Obs. & Mean & Std. Dev. & Min. & Max. & Median \\
\hline Profit-shifting & 27,103 & 0.81 & 0.58 & 0 & 3.12 & 0.72 \\
\hline Democracy polity & 27,103 & 8.89 & 1.63 & 0 & 10 & 9 \\
\hline Democracy polity (IV) & 27,154 & 9.45 & 1.59 & -1.64 & 12.64 & 9.53 \\
\hline Competitiveness of executive recruitment & 27,154 & 2.97 & 0.29 & 1.04 & 3.66 & 2.97 \\
\hline Executive constraints & 27,154 & 6.76 & 0.72 & 1.95 & 8.70 & 6.78 \\
\hline Competitiveness of participation & 27,154 & 4.71 & 0.60 & 0.43 & 5.29 & 4.79 \\
\hline Democracy FH & 27,177 & 9.44 & 1.28 & 1.17 & 10 & 9.75 \\
\hline Personal autonomy and individual rights & 27,154 & 14.59 & 1.21 & 5.83 & 14.84 & 14.51 \\
\hline Political pluralism and participation & 27,154 & 15.22 & 1.95 & 1.10 & 15.64 & 15.03 \\
\hline Political rights & 27,154 & 1.20 & 0.78 & 1.03 & 6.88 & 1.20 \\
\hline Rule of law FH & 27,154 & 13.87 & 1.87 & 0.31 & 14.26 & 13.84 \\
\hline Democracy BMR & 17,217 & 0.98 & 0.14 & 0 & 1 & 1 \\
\hline Control of corruption & 27,154 & 1.19 & 0.76 & -1.27 & 2.40 & 1.47 \\
\hline Rule of law & 27,154 & 1.22 & 0.62 & -1.18 & 2.10 & 1.43 \\
\hline Regulatory quality & 27,154 & 1.13 & 0.50 & -0.95 & 2.26 & 1.16 \\
\hline Firm size (subsidiary) & 27,103 & 9.86 & 2.17 & 0.54 & 18.24 & 9.77 \\
\hline Firm size (MNE) & 27,103 & 15.98 & 1.82 & 7.46 & 19.83 & 16.10 \\
\hline Leverage (subsidiary) & 27,103 & 0.56 & 0.28 & 0 & 1.43 & 0.58 \\
\hline Leverage (MNE) & 27,103 & 0.62 & 0.17 & 0.01 & 2.14 & 0.62 \\
\hline Tangibility (subsidiary) & 27,103 & 0.26 & 0.29 & 0 & 1 & 0.15 \\
\hline Tangibility (MNE) & 27,103 & 0.58 & 0.16 & 0 & 1 & 0.59 \\
\hline Cost of employees (MNE) & 27,103 & 13.52 & 2.30 & 2.52 & 17.39 & 13.78 \\
\hline GDP per capita (subsidiary) & 27,103 & 10.47 & 0.73 & 6.44 & 11.60 & 10.64 \\
\hline GDP per capita (MNE) & 27,103 & 10.70 & 0.48 & 7.20 & 11.60 & 10.73 \\
\hline GDP growth (subsidiary) & 27,103 & 0.26 & 0.98 & -4.26 & 2.72 & 0.41 \\
\hline GDP growth (MNE) & 27,103 & 0.65 & 0.75 & -4.26 & 3.24 & 0.66 \\
\hline Population (subsidiary) & 27,103 & 17.35 & 1.20 & 13.14 & 21.05 & 17.90 \\
\hline Population (MNE) & 27,103 & 17.77 & 1.41 & 12.71 & 21.02 & 18.00 \\
\hline Composite tax variable & 27,103 & 0.10 & 0.05 & 0.03 & 0.48 & 0.09 \\
\hline
\end{tabular}


Table 3. Democracy and Profit-Shifting: OLS estimates

The table reports coefficients and $t$-statistics (in brackets). The dependent variable is Profitshifting. We define all variables in Table 1. Estimation method is OLS with standard errors clustered by both subsidiary's and MNE's country. The lower part of the table denotes the type of fixed effects used in each specification. The *,**, and *** marks denote statistical significance at the $10 \%, 5 \%$, and $1 \%$ level, respectively.

\begin{tabular}{|c|c|c|c|c|}
\hline & (1) & (2) & (3) & (4) \\
\hline \multirow[t]{2}{*}{ Democracy polity } & $-0.169 * * *$ & $-0.103 * * *$ & $-0.104 * * *$ & $-0.121 * *$ \\
\hline & {$[-3.114]$} & {$[-2.808]$} & {$[-2.720]$} & {$[-2.662]$} \\
\hline \multirow[t]{2}{*}{ Firm size (subsidiary) } & $-0.012 * *$ & $-0.012 * *$ & -0.006 & -0.000 \\
\hline & {$[-2.287]$} & {$[-2.372]$} & {$[-1.460]$} & {$[-0.037]$} \\
\hline \multirow[t]{2}{*}{ Firm size (MNE) } & -0.009 & -0.009 & $-0.013 * * *$ & -0.021 \\
\hline & {$[-1.131]$} & {$[-1.205]$} & {$[-3.235]$} & {$[-1.409]$} \\
\hline \multirow[t]{2}{*}{ Leverage (subsidiary) } & 0.024 & 0.026 & 0.015 & -0.007 \\
\hline & {$[0.676]$} & {$[0.730]$} & {$[0.536]$} & {$[-0.216]$} \\
\hline \multirow[t]{2}{*}{ Leverage (MNE) } & -0.111 & -0.114 & $-0.133^{*}$ & 0.019 \\
\hline & {$[-1.260]$} & {$[-1.277]$} & {$[-1.852]$} & [0.187] \\
\hline \multirow[t]{2}{*}{ Tangibility (subsidiary) } & $-0.038 * * *$ & $-0.037 * *$ & -0.010 & -0.012 \\
\hline & {$[-2.769]$} & {$[-2.461]$} & {$[-0.663]$} & {$[-0.538]$} \\
\hline \multirow[t]{2}{*}{ Tangibility (MNE) } & 0.078 & 0.074 & 0.102 & 0.048 \\
\hline & {$[0.761]$} & {$[0.726]$} & [1.143] & {$[0.433]$} \\
\hline \multirow[t]{2}{*}{ Cost of employees (MNE) } & $-0.027 * * *$ & $-0.026 * * *$ & $-0.029 * * *$ & 0.004 \\
\hline & {$[-4.753]$} & {$[-4.497]$} & {$[-6.478]$} & [0.319] \\
\hline \multirow{2}{*}{ GDP per capita (subsidiary) } & -0.252 & -0.434 & -0.490 & -0.706 \\
\hline & {$[-0.380]$} & {$[-0.626]$} & {$[-0.708]$} & {$[-1.165]$} \\
\hline \multirow[t]{2}{*}{ GDP per capita (MNE) } & 0.012 & 0.005 & -0.001 & $0.366^{* * *}$ \\
\hline & {$[0.584]$} & {$[0.261]$} & {$[-0.035]$} & [4.773] \\
\hline \multirow[t]{2}{*}{ GDP growth (subsidiary) } & $0.010 * *$ & $-0.025^{* * *}$ & $-0.025 * *$ & $-0.031 * * *$ \\
\hline & {$[2.041]$} & {$[-2.971]$} & {$[-2.426]$} & {$[-3.320]$} \\
\hline \multirow[t]{2}{*}{ GDP growth (MNE) } & $0.029^{* *}$ & $0.027 * *$ & $0.023^{* *}$ & -0.017 \\
\hline & {$[2.674]$} & {$[2.227]$} & {$[2.256]$} & {$[-1.119]$} \\
\hline \multirow{2}{*}{ Population (subsidiary) } & $6.221 * *$ & 1.148 & 1.354 & 3.093 \\
\hline & [2.469] & {$[0.671]$} & {$[0.771]$} & {$[1.265]$} \\
\hline \multirow[t]{2}{*}{ Population (MNE) } & $0.043 * * *$ & $0.040 * * *$ & $0.034 * * *$ & -1.136 \\
\hline & {$[5.226]$} & {$[5.210]$} & {$[4.540]$} & {$[-0.904]$} \\
\hline \multirow[t]{2}{*}{ Constant } & $-103.274 * *$ & -13.810 & -16.576 & -27.840 \\
\hline & {$[-2.603]$} & {$[-0.484]$} & {$[-0.564]$} & {$[-0.614]$} \\
\hline Observations & 29,242 & 29,242 & 29,241 & 27,103 \\
\hline Adjusted R-squared & 0.266 & 0.273 & 0.313 & 0.776 \\
\hline Year effects & $\mathrm{N}$ & $\mathrm{Y}$ & Y & Y \\
\hline Subsidiary effects & $\mathrm{N}$ & $\mathrm{N}$ & $\mathrm{N}$ & $\mathrm{Y}$ \\
\hline Sub. country effects & Y & Y & $\mathrm{Y}$ & $\mathrm{N}$ \\
\hline Sub. industry effects & $\mathrm{N}$ & $\mathrm{N}$ & $\mathrm{Y}$ & $\mathrm{N}$ \\
\hline Clustered standard errors & country & country & country & country \\
\hline
\end{tabular}


Table 4. Democracy and Profit-Shifting (Alternative Indices of Democracy): OLS Estimates

The table reports coefficients and $t$-statistics (in brackets). The dependent variable is Profit-shifting. We define all variables in Table 1. Estimation method is OLS with standard errors clustered by both subsidiary's and MNE's country. The lower part of the table denotes the type of fixed effects. The *,**, and *** marks denote statistical significance at the $10 \%, 5 \%$, and $1 \%$ level, respectively.

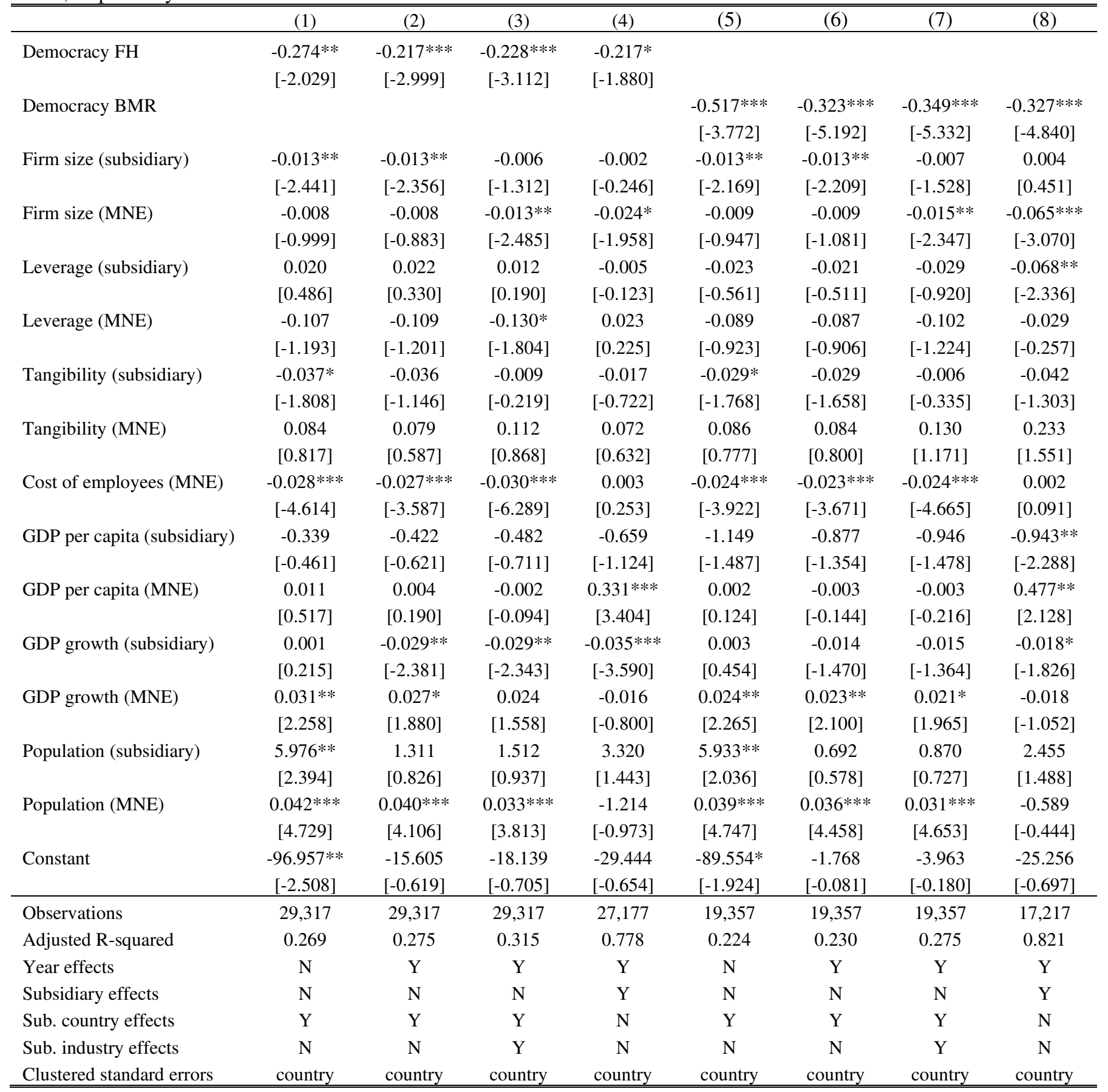


Table 5. Democracy and Profit-Shifting: IV estimates

The table reports coefficients and $t$-statistics (in brackets). The dependent variable is Profitshifting. We define all variables in Table 1. Estimation method is IV with standard errors clustered by both subsidiary's and MNE's country. The intermediate part of the table shows the main first-stage results (common across all regressions). The lower part of the table denotes the type of fixed effects used in each specification. The *,**, and *** marks denote statistical significance at the $10 \%, 5 \%$, and $1 \%$ level, respectively.

\begin{tabular}{|c|c|c|c|c|}
\hline & (1) & (2) & (3) & (4) \\
\hline \multirow[t]{2}{*}{ Democracy polity } & $-0.153 * *$ & $-0.137 * *$ & $-0.144 * *$ & $-0.190 * * *$ \\
\hline & {$[-2.285]$} & {$[-2.021]$} & {$[-2.088]$} & {$[-2.732]$} \\
\hline \multirow[t]{2}{*}{ Firm size (subsidiary) } & $-0.013 * *$ & $-0.013 * *$ & -0.006 & -0.001 \\
\hline & {$[-2.408]$} & {$[-2.492]$} & {$[-1.496]$} & {$[-0.061]$} \\
\hline \multirow[t]{2}{*}{ Firm size (MNE) } & -0.008 & -0.008 & $-0.013 * * *$ & -0.020 \\
\hline & {$[-1.036]$} & {$[-1.102]$} & {$[-3.269]$} & {$[-1.408]$} \\
\hline \multirow[t]{2}{*}{ Leverage (subsidiary) } & 0.020 & 0.022 & 0.013 & -0.009 \\
\hline & [0.563] & {$[0.625]$} & [0.469] & {$[-0.237]$} \\
\hline \multirow[t]{2}{*}{ Leverage (MNE) } & -0.108 & -0.111 & $-0.131 *$ & 0.019 \\
\hline & {$[-1.237]$} & {$[-1.252]$} & {$[-1.838]$} & [0.191] \\
\hline \multirow[t]{2}{*}{ Tangibility (subsidiary) } & $-0.037 * * *$ & $-0.036 * *$ & -0.009 & -0.010 \\
\hline & {$[-2.755]$} & [-2.549] & {$[-0.583]$} & {$[-0.448]$} \\
\hline \multirow[t]{2}{*}{ Tangibility (MNE) } & 0.085 & 0.080 & 0.113 & 0.063 \\
\hline & {$[0.805]$} & {$[0.773]$} & [1.249] & {$[0.542]$} \\
\hline \multirow[t]{2}{*}{ Cost of employees (MNE) } & $-0.028 * * *$ & $-0.027 * * *$ & $-0.030 * * *$ & 0.002 \\
\hline & {$[-4.887]$} & [-4.649] & {$[-6.546]$} & {$[0.180]$} \\
\hline \multirow[t]{2}{*}{ GDP per capita (subsidiary) } & -0.386 & -0.504 & -0.570 & -0.833 \\
\hline & {$[-0.540]$} & {$[-0.687]$} & {$[-0.772]$} & {$[-1.241]$} \\
\hline \multirow{2}{*}{ GDP per capita (MNE) } & 0.011 & 0.004 & -0.001 & $0.379 * * *$ \\
\hline & {$[0.518]$} & {$[0.211]$} & {$[-0.070]$} & {$[5.581]$} \\
\hline \multirow[t]{2}{*}{ GDP growth (subsidiary) } & -0.004 & $-0.035 * * *$ & $-0.035 * * *$ & $-0.044 * * *$ \\
\hline & {$[-0.638]$} & {$[-3.214]$} & {$[-3.010]$} & [-4.819] \\
\hline \multirow[t]{2}{*}{ GDP growth (MNE) } & $0.029 * *$ & $0.026^{* *}$ & $0.023^{*}$ & -0.018 \\
\hline & [2.503] & [2.024] & [1.967] & {$[-1.131]$} \\
\hline \multirow[t]{2}{*}{ Population (subsidiary) } & $5.851 * *$ & 1.037 & 1.217 & 3.160 \\
\hline & {$[2.307]$} & {$[0.614]$} & {$[0.700]$} & {$[1.303]$} \\
\hline \multirow[t]{2}{*}{ Population (MNE) } & $0.042 * * *$ & $0.040 * * *$ & $0.034 * * *$ & -0.932 \\
\hline & [4.886] & [4.919] & {$[4.435]$} & {$[-0.758]$} \\
\hline \multirow[t]{2}{*}{ Constant } & $-95.448 * *$ & -10.753 & -12.918 & -30.688 \\
\hline & {$[-2.351]$} & {$[-0.380]$} & {$[-0.443]$} & {$[-0.685]$} \\
\hline \multicolumn{5}{|l|}{ First stage results } \\
\hline Regional democratization & $\begin{array}{c}11.883 * * * \\
{[3.92]} \\
\end{array}$ & & & \\
\hline Observations & 29,294 & 29,294 & 29,294 & 27,154 \\
\hline Adjusted R-squared & 0.268 & 0.275 & 0.315 & 0.779 \\
\hline Year effects & $\mathrm{N}$ & Y & Y & Y \\
\hline Subsidiary effects & $\mathrm{N}$ & $\mathrm{N}$ & $\mathrm{N}$ & Y \\
\hline Sub. country effects & $\mathrm{Y}$ & $\mathrm{Y}$ & Y & $\mathrm{N}$ \\
\hline Sub. industry effects & $\mathrm{N}$ & $\mathrm{N}$ & Y & $\mathrm{N}$ \\
\hline Clustered standard errors & country & country & country & country \\
\hline
\end{tabular}


Table 6. Medium and Longer-Term Effects of Democratic Development

The table reports coefficients and $t$-statistics (in brackets). The dependent variable is Profit-shifting, and most variables are defined in Table 1. Estimation method is our baseline IV procedure with standard errors clustered by both subsidiary's and MNE's country. The lower part of the table denotes the type of fixed effects used in each specification. The *,**, and *** marks denote statistical significance at the $10 \%, 5 \%$, and $1 \%$ level, respectively.

\begin{tabular}{|c|c|c|c|c|c|}
\hline & $(1)$ & (2) & (3) & (4) & (5) \\
\hline Democracy polity & $\begin{array}{c}-0.190 * * * \\
{[-2.732]}\end{array}$ & $\begin{array}{c}-0.261 * * * \\
{[-3.507]}\end{array}$ & $\begin{array}{c}-0.271 * * * \\
{[-2.705]}\end{array}$ & $\begin{array}{c}-0.319 * * \\
{[-2.195]}\end{array}$ & $\begin{array}{c}-0.448 * * \\
{[-2.140]}\end{array}$ \\
\hline Democracy polity (t-1) & & $\begin{array}{c}0.029 \\
{[0.479]}\end{array}$ & $\begin{array}{c}-0.093 * * \\
{[-2.059]}\end{array}$ & $\begin{array}{c}-0.131 * * \\
{[-2.326]}\end{array}$ & $\begin{array}{c}-0.151 * * \\
{[-2.642]}\end{array}$ \\
\hline Democracy polity (t-2) & & & $\begin{array}{c}0.177 \\
{[0.870]}\end{array}$ & $\begin{array}{c}-0.059 \\
{[-1.029]}\end{array}$ & $\begin{array}{l}-0.150^{*} \\
{[-2.034]}\end{array}$ \\
\hline Democracy polity (t-3) & & & & $\begin{array}{c}0.003 \\
{[0.048]}\end{array}$ & $\begin{array}{c}0.049 \\
{[0.435]}\end{array}$ \\
\hline Democracy polity (t-4) & & & & & $\begin{array}{c}-0.106 \\
{[-0.810]}\end{array}$ \\
\hline Firm size (subsidiary) & $\begin{array}{c}-0.001 \\
{[-0.061]}\end{array}$ & $\begin{array}{c}0.002 \\
{[0.230]}\end{array}$ & $\begin{array}{c}0.000 \\
{[0.008]}\end{array}$ & $\begin{array}{c}0.014 \\
{[1.063]}\end{array}$ & $\begin{array}{c}0.004 \\
{[0.360]}\end{array}$ \\
\hline Firm size (MNE) & $\begin{array}{c}-0.020 \\
{[-1.408]}\end{array}$ & $\begin{array}{c}-0.032 \\
{[-1.507]}\end{array}$ & $\begin{array}{c}-0.042 * * \\
{[-2.077]}\end{array}$ & $\begin{array}{c}-0.054 \\
{[-1.602]}\end{array}$ & $\begin{array}{c}-0.039 * * \\
{[-2.066]}\end{array}$ \\
\hline Leverage (subsidiary) & $\begin{array}{c}-0.009 \\
{[-0.237]}\end{array}$ & $\begin{array}{c}0.000 \\
{[0.002]}\end{array}$ & $\begin{array}{c}-0.002 \\
{[-0.040]}\end{array}$ & $\begin{array}{c}-0.027 \\
{[-0.995]}\end{array}$ & $\begin{array}{c}0.010 \\
{[0.480]}\end{array}$ \\
\hline Leverage (MNE) & $\begin{array}{c}0.019 \\
{[0.191]}\end{array}$ & $\begin{array}{c}0.052 \\
{[0.459]}\end{array}$ & $\begin{array}{c}0.081 \\
{[1.001]}\end{array}$ & $\begin{array}{l}0.122^{*} \\
{[1.901]}\end{array}$ & $\begin{array}{c}0.133 * * \\
{[2.146]}\end{array}$ \\
\hline Tangibility (subsidiary) & $\begin{array}{c}-0.010 \\
{[-0.448]}\end{array}$ & $\begin{array}{c}-0.009 \\
{[-0.522]}\end{array}$ & $\begin{array}{c}-0.003 \\
{[-0.168]}\end{array}$ & $\begin{array}{l}-0.044^{*} \\
{[-1.875]}\end{array}$ & $\begin{array}{c}-0.072 * * \\
{[-2.180]}\end{array}$ \\
\hline Tangibility (MNE) & $\begin{array}{c}0.063 \\
{[0.542]}\end{array}$ & $\begin{array}{c}-0.001 \\
{[-0.011]}\end{array}$ & $\begin{array}{c}0.017 \\
{[0.214]}\end{array}$ & $\begin{array}{c}0.083 \\
{[0.769]}\end{array}$ & $\begin{array}{c}-0.027 \\
{[-0.336]}\end{array}$ \\
\hline Cost of employees (MNE) & $\begin{array}{c}0.002 \\
{[0.180]}\end{array}$ & $\begin{array}{c}0.005 \\
{[0.503]}\end{array}$ & $\begin{array}{l}0.011^{*} \\
{[1.746]}\end{array}$ & $\begin{array}{c}0.020 * * \\
{[2.637]}\end{array}$ & $\begin{array}{c}0.026^{*} \\
{[1.729]}\end{array}$ \\
\hline GDP per capita (subsidiary) & $\begin{array}{c}-0.833 \\
{[-1.241]}\end{array}$ & $\begin{array}{c}-0.600 \\
{[-0.754]}\end{array}$ & $\begin{array}{c}0.317 \\
{[0.374]}\end{array}$ & $\begin{array}{c}0.359 \\
{[0.421]}\end{array}$ & $\begin{array}{c}0.797 \\
{[0.925]}\end{array}$ \\
\hline GDP per capita (MNE) & $\begin{array}{c}0.379 * * * \\
{[5.581]}\end{array}$ & $\begin{array}{c}0.334 * * * \\
{[3.332]}\end{array}$ & $\begin{array}{l}0.152 * * \\
{[2.365]}\end{array}$ & $\begin{array}{c}0.139 * * \\
{[2.351]}\end{array}$ & $\begin{array}{c}0.137^{*} \\
{[1.824]}\end{array}$ \\
\hline GDP growth (subsidiary) & $\begin{array}{c}-0.044 * * * \\
{[-4.819]}\end{array}$ & $\begin{array}{c}-0.003 \\
{[-0.097]}\end{array}$ & $\begin{array}{c}0.034 \\
{[0.856]}\end{array}$ & $\begin{array}{c}0.032 \\
{[0.805]}\end{array}$ & $\begin{array}{c}0.064 \\
{[0.797]}\end{array}$ \\
\hline GDP growth (MNE) & $\begin{array}{c}-0.018 \\
{[-1.131]}\end{array}$ & $\begin{array}{c}-0.013 \\
{[-1.279]}\end{array}$ & $\begin{array}{c}-0.001 \\
{[-0.051]}\end{array}$ & $\begin{array}{c}-0.010 \\
{[-0.546]}\end{array}$ & $\begin{array}{c}-0.007 \\
{[-0.340]}\end{array}$ \\
\hline Population (subsidiary) & $\begin{array}{c}3.160 \\
{[1.303]}\end{array}$ & $\begin{array}{c}3.333 \\
{[1.247]}\end{array}$ & $\begin{array}{c}4.055 \\
{[1.543]}\end{array}$ & $\begin{array}{c}2.091 \\
{[0.734]}\end{array}$ & $\begin{array}{c}1.745 \\
{[0.908]}\end{array}$ \\
\hline Population (MNE) & $\begin{array}{c}-0.932 \\
{[-0.758]}\end{array}$ & $\begin{array}{c}-0.794 \\
{[-0.570]}\end{array}$ & $\begin{array}{c}-0.723 \\
{[-0.512]}\end{array}$ & $\begin{array}{c}-1.468 \\
{[-1.121]}\end{array}$ & $\begin{array}{l}-2.647 \\
{[-1.437]}\end{array}$ \\
\hline Constant & $\begin{array}{l}-30.688 \\
{[-0.685]}\end{array}$ & $\begin{array}{l}-37.427 \\
{[-0.747]}\end{array}$ & $\begin{array}{l}-58.937 \\
{[-1.283]}\end{array}$ & $\begin{array}{c}-9.101 \\
{[-0.189]}\end{array}$ & $\begin{array}{r}15.768 \\
{[0.358]} \\
\end{array}$ \\
\hline Observations & 27,154 & 21,215 & 15,761 & 11,888 & 8,952 \\
\hline Adjusted R-squared & 0.779 & 0.801 & 0.837 & 0.884 & 0.900 \\
\hline Year effects & $\mathrm{Y}$ & Y & $\mathrm{Y}$ & Y & $\mathrm{Y}$ \\
\hline Subsidiary effects & $\mathrm{Y}$ & $\mathrm{Y}$ & $\mathrm{Y}$ & $\mathrm{Y}$ & $\mathrm{Y}$ \\
\hline Sub. country effects & $\mathrm{N}$ & $\mathrm{N}$ & $\mathrm{N}$ & $\mathrm{N}$ & $\mathrm{N}$ \\
\hline $\begin{array}{l}\text { Sub. industry effects } \\
\text { Clustered standard errors }\end{array}$ & $\begin{array}{c}\mathrm{N} \\
\text { country }\end{array}$ & $\begin{array}{c}\mathrm{N} \\
\text { country }\end{array}$ & $\begin{array}{c}\mathrm{N} \\
\text { country }\end{array}$ & $\begin{array}{c}\mathrm{N} \\
\text { country }\end{array}$ & $\begin{array}{c}\mathrm{N} \\
\text { country }\end{array}$ \\
\hline
\end{tabular}


Table 7. Components of the Democracy (Polity IV) Index: IV Estimates

The table reports coefficients and $t$-statistics (in brackets). The dependent variable is Profitshifting and the main independent variables are the components of the Polity IV index denoted in lines 2 to 4 of the table. We define all variables in Table 1 . The estimation method is IV, with standard errors clustered by both subsidiary and MNE country. The lower part of the table denotes the type of fixed effects. The *,**, and *** marks denote statistical significance at the $10 \%, 5 \%$, and $1 \%$ level, respectively.

\begin{tabular}{|c|c|c|c|}
\hline & $(1)$ & (2) & (3) \\
\hline Competitiveness of executive recruitment & $\begin{array}{c}-1.179 * * * \\
{[-2.729]}\end{array}$ & & \\
\hline Executive constraints & & $\begin{array}{c}-0.388 * * * \\
{[-2.728]}\end{array}$ & \\
\hline Competitiveness of participation & & & $\begin{array}{c}-0.554 * * * \\
{[-2.731]}\end{array}$ \\
\hline Firm size (subsidiary) & $\begin{array}{c}-0.001 \\
{[-0.061]}\end{array}$ & $\begin{array}{c}-0.001 \\
{[-0.061]}\end{array}$ & $\begin{array}{c}-0.001 \\
{[-0.061]}\end{array}$ \\
\hline Firm size (MNE) & $\begin{array}{c}-0.020 \\
{[-1.409]}\end{array}$ & $\begin{array}{c}-0.020 \\
{[-1.410]}\end{array}$ & $\begin{array}{c}-0.020 \\
{[-1.408]}\end{array}$ \\
\hline Leverage (subsidiary) & $\begin{array}{c}-0.009 \\
{[-0.237]}\end{array}$ & $\begin{array}{c}-0.009 \\
{[-0.237]}\end{array}$ & $\begin{array}{c}-0.009 \\
{[-0.237]}\end{array}$ \\
\hline Leverage (MNE) & $\begin{array}{c}0.019 \\
{[0.191]}\end{array}$ & $\begin{array}{c}0.019 \\
{[0.191]}\end{array}$ & $\begin{array}{c}0.019 \\
{[0.191]}\end{array}$ \\
\hline Tangibility (subsidiary) & $\begin{array}{c}-0.010 \\
{[-0.449]}\end{array}$ & $\begin{array}{c}-0.010 \\
{[-0.448]}\end{array}$ & $\begin{array}{c}-0.010 \\
{[-0.448]}\end{array}$ \\
\hline Tangibility (MNE) & $\begin{array}{c}0.063 \\
{[0.542]}\end{array}$ & $\begin{array}{c}0.063 \\
{[0.542]}\end{array}$ & $\begin{array}{c}0.063 \\
{[0.542]}\end{array}$ \\
\hline Cost of employees (MNE) & $\begin{array}{c}0.002 \\
{[0.181]}\end{array}$ & $\begin{array}{c}0.002 \\
{[0.181]}\end{array}$ & $\begin{array}{c}0.002 \\
{[0.181]}\end{array}$ \\
\hline GDP per capita (subsidiary) & $\begin{array}{c}-0.818 \\
{[-1.225]}\end{array}$ & $\begin{array}{c}-0.931 \\
{[-1.346]}\end{array}$ & $\begin{array}{c}-0.706 \\
{[-1.093]}\end{array}$ \\
\hline GDP per capita (MNE) & $\begin{array}{c}0.379 * * * \\
{[5.550]}\end{array}$ & $\begin{array}{c}0.379 * * * \\
{[5.548]}\end{array}$ & $\begin{array}{c}0.379 * * * \\
{[5.564]}\end{array}$ \\
\hline GDP growth (subsidiary) & $\begin{array}{c}-0.076^{* * * *} \\
{[-4.417]}\end{array}$ & $\begin{array}{c}-0.032 * * * \\
{[-3.693]}\end{array}$ & $\begin{array}{c}-0.049 * * * \\
{[-4.943]}\end{array}$ \\
\hline GDP growth (MNE) & $\begin{array}{c}-0.018 \\
{[-1.131]}\end{array}$ & $\begin{array}{c}-0.018 \\
{[-1.131]}\end{array}$ & $\begin{array}{c}-0.018 \\
{[-1.131]}\end{array}$ \\
\hline Population (subsidiary) & $\begin{array}{c}3.111 \\
{[1.286]}\end{array}$ & $\begin{array}{c}3.139 \\
{[1.295]}\end{array}$ & $\begin{array}{c}3.210 \\
{[1.320]}\end{array}$ \\
\hline Population (MNE) & $\begin{array}{c}-0.932 \\
{[-0.758]}\end{array}$ & $\begin{array}{c}-0.932 \\
{[-0.758]}\end{array}$ & $\begin{array}{c}-0.932 \\
{[-0.758]}\end{array}$ \\
\hline Constant & $\begin{array}{l}-28.276 \\
{[-0.634]}\end{array}$ & $\begin{array}{l}-28.461 \\
{[-0.638]}\end{array}$ & $\begin{array}{l}-32.074 \\
{[-0.714]}\end{array}$ \\
\hline Observations & 27,154 & 27,154 & 27,154 \\
\hline Adjusted R-squared & 0.779 & 0.779 & 0.779 \\
\hline Year effects & $\mathrm{Y}$ & Y & $\mathrm{Y}$ \\
\hline Subsidiary effects & $\mathrm{Y}$ & Y & $\mathrm{Y}$ \\
\hline Sub. country effects & $\mathrm{N}$ & $\mathrm{N}$ & $\mathrm{N}$ \\
\hline Sub. industry effects & $\mathrm{N}$ & $\mathrm{N}$ & $\mathrm{N}$ \\
\hline Clustered standard errors & country & country & country \\
\hline
\end{tabular}


Table 8. Components of the Democracy (Freedom House) Index: IV Estimates

The table reports coefficients and $t$-statistics (in brackets). The dependent variable is Profit-shifting and the main independent variables are the components of the Freedom House index denoted in lines 2 to 5 of the table. We define all variables in Table 1 . The estimation method is IV, with standard errors clustered by both subsidiary and MNE country. The lower part of the table denotes the type of fixed effects. The ${ }^{*}, * *$, and $* * *$ marks denote statistical significance at the $10 \%, 5 \%$, and $1 \%$ level, respectively.

\begin{tabular}{|c|c|c|c|c|}
\hline & $(1)$ & $(2)$ & (3) & (4) \\
\hline Personal autonomy and individual rights & $\begin{array}{c}-0.358 * * * \\
{[-2.732]}\end{array}$ & & & \\
\hline Political pluralism and participation & & $\begin{array}{c}-0.163 * * * \\
{[-2.732]}\end{array}$ & & \\
\hline Political rights & & & $\begin{array}{c}0.425 * * * \\
{[2.733]}\end{array}$ & \\
\hline Rule of law FH & & & & $\begin{array}{c}-0.195 * * * \\
{[-2.733]}\end{array}$ \\
\hline Firm size (subsidiary) & $\begin{array}{c}-0.001 \\
{[-0.061]}\end{array}$ & $\begin{array}{c}-0.001 \\
{[-0.061]}\end{array}$ & $\begin{array}{c}-0.001 \\
{[-0.060]}\end{array}$ & $\begin{array}{c}-0.001 \\
{[-0.060]}\end{array}$ \\
\hline Firm size (MNE) & $\begin{array}{c}-0.020 \\
{[-1.407]}\end{array}$ & $\begin{array}{c}-0.020 \\
{[-1.408]}\end{array}$ & $\begin{array}{c}-0.020 \\
{[-1.404]}\end{array}$ & $\begin{array}{c}-0.020 \\
{[-1.407]}\end{array}$ \\
\hline Leverage (subsidiary) & $\begin{array}{c}-0.009 \\
{[-0.237]}\end{array}$ & $\begin{array}{c}-0.009 \\
{[-0.237]}\end{array}$ & $\begin{array}{c}-0.009 \\
{[-0.236]}\end{array}$ & $\begin{array}{c}-0.009 \\
{[-0.237]}\end{array}$ \\
\hline Leverage (MNE) & $\begin{array}{c}0.019 \\
{[0.191]}\end{array}$ & $\begin{array}{c}0.019 \\
{[0.191]}\end{array}$ & $\begin{array}{c}0.019 \\
{[0.191]}\end{array}$ & $\begin{array}{c}0.019 \\
{[0.191]}\end{array}$ \\
\hline Tangibility (subsidiary) & $\begin{array}{c}-0.010 \\
{[-0.448]}\end{array}$ & $\begin{array}{c}-0.010 \\
{[-0.448]}\end{array}$ & $\begin{array}{c}-0.010 \\
{[-0.448]}\end{array}$ & $\begin{array}{c}-0.010 \\
{[-0.448]}\end{array}$ \\
\hline Tangibility (MNE) & $\begin{array}{c}0.063 \\
{[0.542]}\end{array}$ & $\begin{array}{c}0.063 \\
{[0.542]}\end{array}$ & $\begin{array}{c}0.063 \\
{[0.541]}\end{array}$ & $\begin{array}{c}0.063 \\
{[0.542]}\end{array}$ \\
\hline Cost of employees (MNE) & $\begin{array}{c}0.002 \\
{[0.180]}\end{array}$ & $\begin{array}{c}0.002 \\
{[0.180]}\end{array}$ & $\begin{array}{c}0.002 \\
{[0.180]}\end{array}$ & $\begin{array}{c}0.002 \\
{[0.180]}\end{array}$ \\
\hline GDP per capita (subsidiary) & $\begin{array}{c}-0.321 \\
{[-0.548]}\end{array}$ & $\begin{array}{c}-0.717 \\
{[-1.107]}\end{array}$ & $\begin{array}{c}-0.674 \\
{[-1.053]}\end{array}$ & $\begin{array}{c}-0.536 \\
{[-0.870]}\end{array}$ \\
\hline GDP per capita (MNE) & $\begin{array}{c}0.379 * * * \\
{[5.576]}\end{array}$ & $\begin{array}{c}0.379 * * * \\
{[5.581]}\end{array}$ & $\begin{array}{c}0.379 * * * \\
{[5.636]}\end{array}$ & $\begin{array}{c}0.379 * * * \\
{[5.586]}\end{array}$ \\
\hline GDP growth (subsidiary) & $\begin{array}{c}-0.056 * * * \\
{[-4.909]}\end{array}$ & $\begin{array}{c}-0.056 * * * \\
{[-4.898]}\end{array}$ & $\begin{array}{c}-0.083 * * * \\
{[-4.289]}\end{array}$ & $\begin{array}{c}-0.044 * * * \\
{[-4.841]}\end{array}$ \\
\hline GDP growth (MNE) & $\begin{array}{c}-0.018 \\
{[-1.131]}\end{array}$ & $\begin{array}{c}-0.018 \\
{[-1.131]}\end{array}$ & $\begin{array}{c}-0.018 \\
{[-1.131]}\end{array}$ & $\begin{array}{c}-0.018 \\
{[-1.131]}\end{array}$ \\
\hline Population (subsidiary) & $\begin{array}{c}3.084 \\
{[1.276]}\end{array}$ & $\begin{array}{c}3.107 \\
{[1.284]}\end{array}$ & $\begin{array}{c}3.116 \\
{[1.288]}\end{array}$ & $\begin{array}{c}3.134 \\
{[1.294]}\end{array}$ \\
\hline Population (MNE) & $\begin{array}{c}-0.932 \\
{[-0.758]}\end{array}$ & $\begin{array}{c}-0.932 \\
{[-0.758]}\end{array}$ & $\begin{array}{c}-0.932 \\
{[-0.758]}\end{array}$ & $\begin{array}{c}-0.932 \\
{[-0.758]}\end{array}$ \\
\hline Constant & $\begin{array}{l}-31.339 \\
{[-0.698]}\end{array}$ & $\begin{array}{l}-30.300 \\
{[-0.677]}\end{array}$ & $\begin{array}{l}-33.889 \\
{[-0.751]}\end{array}$ & $\begin{array}{l}-32.450 \\
{[-0.722]}\end{array}$ \\
\hline Observations & 27,154 & 27,154 & 27,154 & 27,154 \\
\hline Adjusted R-squared & 0.779 & 0.779 & 0.779 & 0.779 \\
\hline Year effects & $\mathrm{Y}$ & $\mathrm{Y}$ & $\mathrm{Y}$ & $\mathrm{Y}$ \\
\hline Subsidiary effects & $\mathrm{Y}$ & $\mathrm{Y}$ & $\mathrm{Y}$ & $\mathrm{Y}$ \\
\hline Sub. country effects & $\mathrm{N}$ & $\mathrm{N}$ & $\mathrm{N}$ & $\mathrm{N}$ \\
\hline $\begin{array}{l}\text { Sub. industry effects } \\
\text { Clustered standard errors }\end{array}$ & $\begin{array}{c}\mathrm{N} \\
\text { country }\end{array}$ & $\begin{array}{c}\mathrm{N} \\
\text { country }\end{array}$ & $\begin{array}{c}\mathrm{N} \\
\text { country }\end{array}$ & $\begin{array}{c}\mathrm{N} \\
\text { country }\end{array}$ \\
\hline
\end{tabular}


Table 9. Profit-Shifting and Macroeconomic Institutions: IV Estimates

The table reports coefficients and $t$-statistics (in brackets). The dependent variable is Profit-shifting. We define all variables in Table 1. Estimation method is IV with standard errors clustered by both subsidiary's and MNE's country. The lower part of the table denotes the type of fixed effects. The $*, * *$, and $* * *$ marks denote statistical significance at the $10 \%, 5 \%$, and $1 \%$ level, respectively.

\begin{tabular}{|c|c|c|c|c|}
\hline & $(1)$ & (2) & (3) & (4) \\
\hline Democracy polity & $\begin{array}{c}-0.190 * * * \\
{[-2.732]}\end{array}$ & $\begin{array}{c}-0.183 * * \\
{[-2.675]}\end{array}$ & $\begin{array}{c}-0.161 * * \\
{[-2.439]}\end{array}$ & $\begin{array}{c}-0.175 * * * \\
{[-2.737]}\end{array}$ \\
\hline Control of corruption & & $\begin{array}{c}-0.294 \\
{[-0.714]}\end{array}$ & & \\
\hline Rule of law & & & $\begin{array}{c}-0.646 * * * \\
{[-3.078]}\end{array}$ & \\
\hline Regulatory quality & & & & $\begin{array}{c}-0.483 * * \\
{[-2.558]}\end{array}$ \\
\hline Firm size (subsidiary) & $\begin{array}{c}-0.001 \\
{[-0.061]}\end{array}$ & $\begin{array}{c}0.000 \\
{[0.034]}\end{array}$ & $\begin{array}{c}0.000 \\
{[0.046]}\end{array}$ & $\begin{array}{c}0.001 \\
{[0.097]}\end{array}$ \\
\hline Firm size (MNE) & $\begin{array}{c}-0.020 \\
{[-1.408]}\end{array}$ & $\begin{array}{c}-0.021 \\
{[-1.299]}\end{array}$ & $\begin{array}{c}-0.020 \\
{[-1.290]}\end{array}$ & $\begin{array}{c}-0.018 \\
{[-1.366]}\end{array}$ \\
\hline Leverage (subsidiary) & $\begin{array}{c}-0.009 \\
{[-0.237]}\end{array}$ & $\begin{array}{c}-0.011 \\
{[-0.281]}\end{array}$ & $\begin{array}{c}-0.014 \\
{[-0.364]}\end{array}$ & $\begin{array}{c}0.000 \\
{[0.007]}\end{array}$ \\
\hline Leverage (MNE) & $\begin{array}{c}0.019 \\
{[0.191]}\end{array}$ & $\begin{array}{c}0.022 \\
{[0.230]}\end{array}$ & $\begin{array}{c}0.017 \\
{[0.167]}\end{array}$ & $\begin{array}{c}0.013 \\
{[0.122]}\end{array}$ \\
\hline Tangibility (subsidiary) & $\begin{array}{c}-0.010 \\
{[-0.448]}\end{array}$ & $\begin{array}{c}-0.015 \\
{[-0.568]}\end{array}$ & $\begin{array}{c}-0.011 \\
{[-0.458]}\end{array}$ & $\begin{array}{c}-0.019 \\
{[-0.775]}\end{array}$ \\
\hline Tangibility (MNE) & $\begin{array}{c}0.063 \\
{[0.542]}\end{array}$ & $\begin{array}{c}0.061 \\
{[0.511]}\end{array}$ & $\begin{array}{c}0.052 \\
{[0.447]}\end{array}$ & $\begin{array}{c}0.064 \\
{[0.560]}\end{array}$ \\
\hline Cost of employees (MNE) & $\begin{array}{c}0.002 \\
{[0.180]}\end{array}$ & $\begin{array}{c}0.002 \\
{[0.153]}\end{array}$ & $\begin{array}{c}0.001 \\
{[0.049]}\end{array}$ & $\begin{array}{c}0.001 \\
{[0.042]}\end{array}$ \\
\hline GDP per capita (subsidiary) & $\begin{array}{c}-0.833 \\
{[-1.241]}\end{array}$ & $\begin{array}{c}-0.576 \\
{[-0.666]}\end{array}$ & $\begin{array}{c}-0.206 \\
{[-0.326]}\end{array}$ & $\begin{array}{c}-0.472 \\
{[-0.826]}\end{array}$ \\
\hline GDP per capita (MNE) & $\begin{array}{c}0.379 * * * \\
{[5.581]}\end{array}$ & $\begin{array}{c}0.370 * * * \\
{[5.158]}\end{array}$ & $\begin{array}{c}0.377 * * * \\
{[5.722]}\end{array}$ & $\begin{array}{c}0.375^{* * * *} \\
{[4.822]}\end{array}$ \\
\hline GDP growth (subsidiary) & $\begin{array}{c}-0.044 * * * \\
{[-4.819]}\end{array}$ & $\begin{array}{c}-0.054 * * * \\
{[-4.244]}\end{array}$ & $\begin{array}{c}-0.057 * * * \\
{[-4.960]}\end{array}$ & $\begin{array}{c}-0.049 * * * \\
{[-5.747]}\end{array}$ \\
\hline GDP growth (MNE) & $\begin{array}{c}-0.018 \\
{[-1.131]}\end{array}$ & $\begin{array}{c}-0.018 \\
{[-1.198]}\end{array}$ & $\begin{array}{c}-0.019 \\
{[-1.147]}\end{array}$ & $\begin{array}{c}-0.019 \\
{[-1.220]}\end{array}$ \\
\hline Population (subsidiary) & $\begin{array}{c}3.160 \\
{[1.303]}\end{array}$ & $\begin{array}{c}3.308 \\
{[1.396]}\end{array}$ & $\begin{array}{c}2.660 \\
{[1.328]}\end{array}$ & $\begin{array}{c}3.406 \\
{[1.469]}\end{array}$ \\
\hline Population (MNE) & $\begin{array}{c}-0.932 \\
{[-0.758]}\end{array}$ & $\begin{array}{c}-0.958 \\
{[-0.778]}\end{array}$ & $\begin{array}{c}-0.883 \\
{[-0.739]}\end{array}$ & $\begin{array}{c}-0.842 \\
{[-0.703]}\end{array}$ \\
\hline Constant & $\begin{array}{l}-30.688 \\
{[-0.685]}\end{array}$ & $\begin{array}{l}-35.083 \\
{[-0.771]}\end{array}$ & $\begin{array}{l}-28.902 \\
{[-0.736]}\end{array}$ & $\begin{array}{l}-39.897 \\
{[-0.881]}\end{array}$ \\
\hline Observations & 27,154 & 27,154 & 27,154 & 27,154 \\
\hline Adjusted R-squared & 0.779 & 0.780 & 0.782 & 0.782 \\
\hline Year effects & $\mathrm{Y}$ & $\mathrm{Y}$ & $\mathrm{Y}$ & $\mathrm{Y}$ \\
\hline Subsidiary effects & $\mathrm{Y}$ & Y & $\mathrm{Y}$ & $\mathrm{Y}$ \\
\hline Sub. country effects & $\mathrm{N}$ & $\mathrm{N}$ & $\mathrm{N}$ & $\mathrm{N}$ \\
\hline $\begin{array}{l}\text { Sub. industry effects } \\
\text { Clustered standard errors }\end{array}$ & $\begin{array}{c}\mathrm{N} \\
\text { country }\end{array}$ & $\begin{array}{c}\mathrm{N} \\
\text { country }\end{array}$ & $\begin{array}{c}\mathrm{N} \\
\text { country }\end{array}$ & $\begin{array}{c}\mathrm{N} \\
\text { country }\end{array}$ \\
\hline
\end{tabular}


Figure 1. Democracy and Profit-Shifting

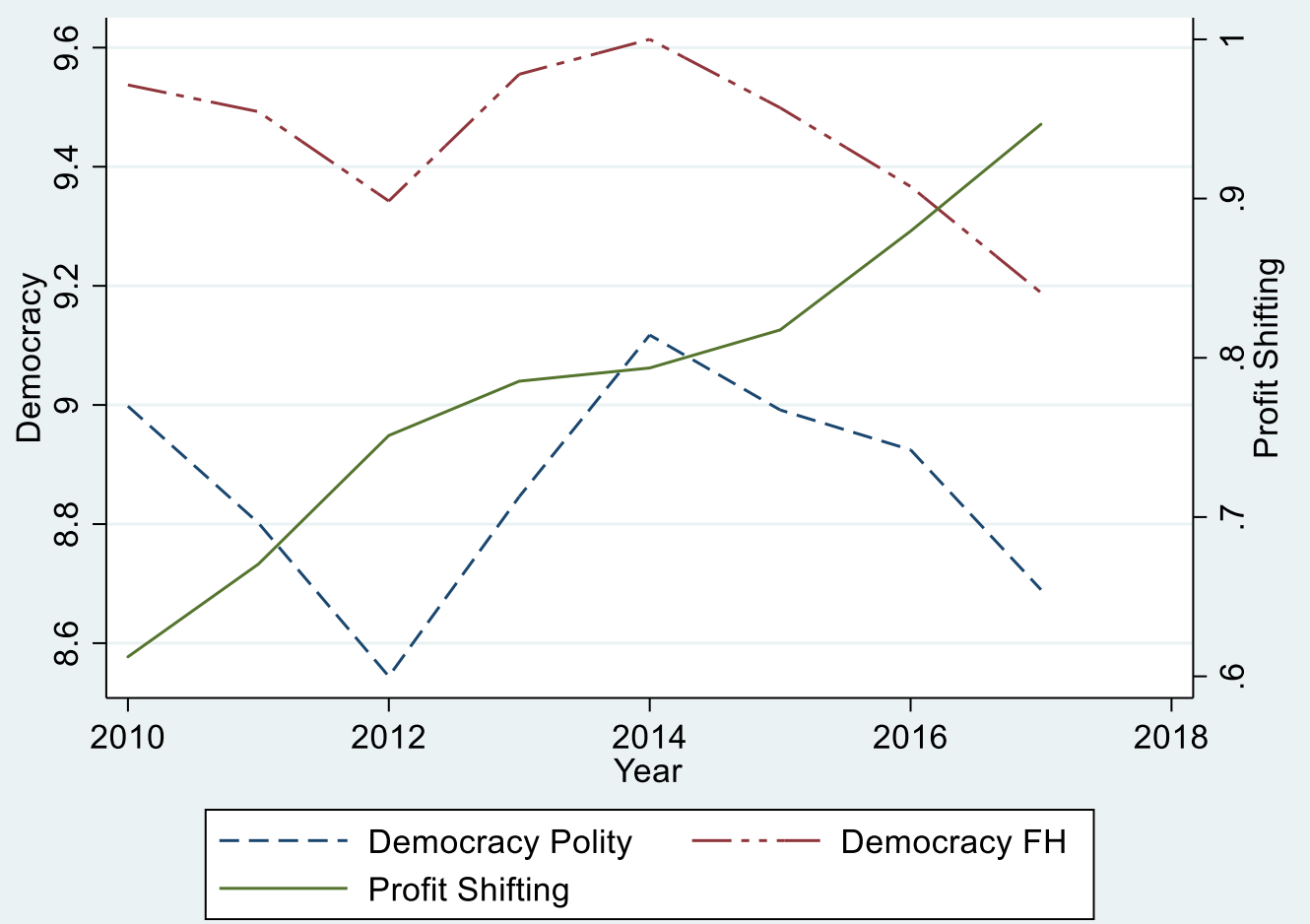


Figure 2. Democracy Polity and Institutions
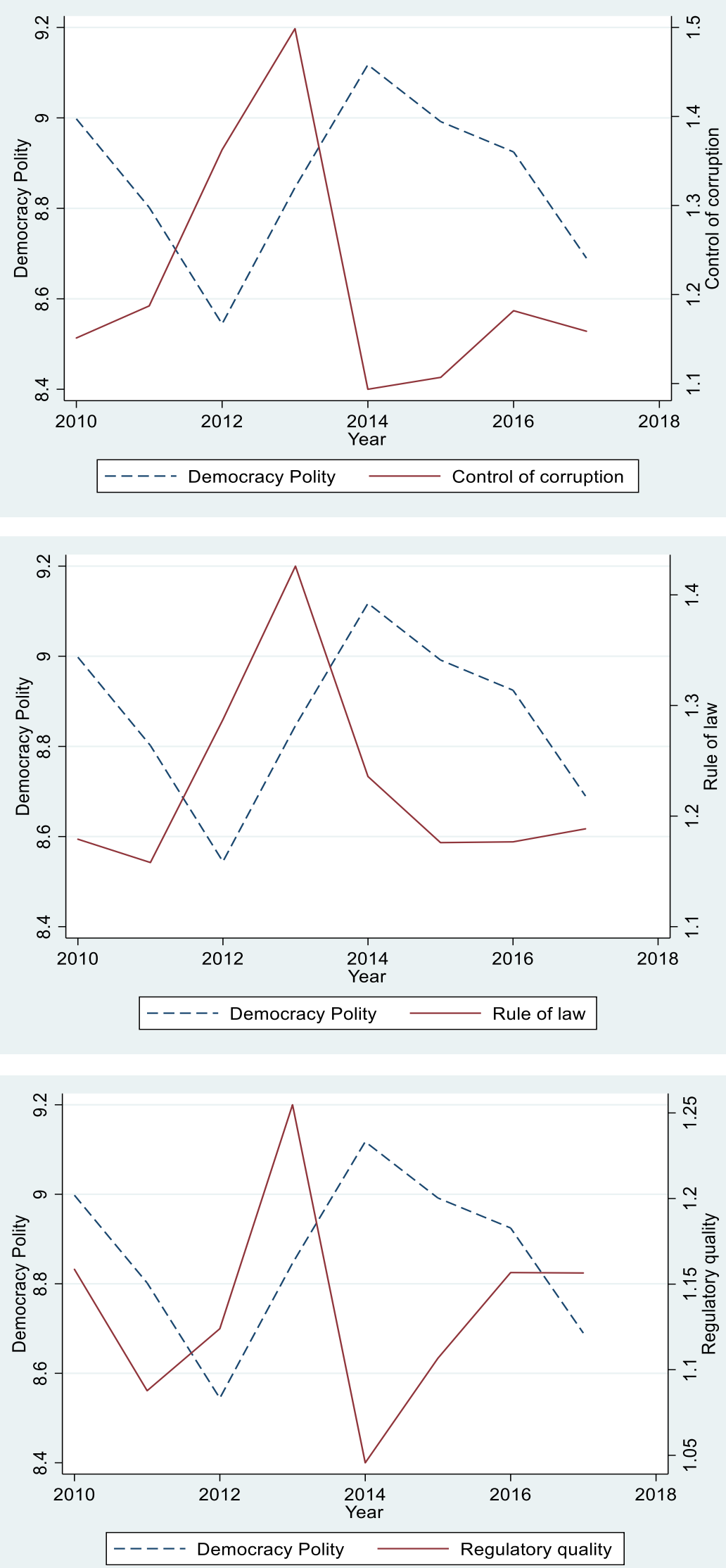


\section{Appendix}

\section{Part A. Sample Construction}

We begin with the full worldwide set of subsidiaries with listed global ultimate owners (GUOs) in Orbis. ${ }^{21}$ This search strategy provides detailed accounting data for the subsidiaries (and not for the GUO). Next, we create a data set for GUO, for which we search for shareholders with foreign subsidiaries anywhere in the world (excluding firms for which the country is not listed). For subsidiaries, we rely on unconsolidated statements; for GUOs we rely on consolidated statements (there are very few unconsolidated statements for GUOs). Consolidated data, which net out potential profit-shifting movements among affiliates of a multinational group, help us control for GUO characteristics potentially affecting the profit-shifting behaviors in equation (3) of our empirical analysis. We then merge the data sets by GUO and year. Both the subsidiaries and their GUO are of one of the following types: (i) very large or large companies, active, with recent detailed financials, (ii) medium-size companies, active, with recent detailed financials, (iii) small companies, active, with recent detailed financials. We exclude public authorities.

Our criterion for specifying a subsidiary is the existence of a GUO that owns at least $25.01 \%$ of the subsidiary. Note also that the minimum percentage of $25.01 \%$ includes both the ultimate owner's direct and indirect holdings, in case there are chains of ownership among the related firms of a specific group. Unlike previous studies, we relax the restriction that GUOs own at least $51 \%$ of their foreign subsidiaries, as one might expect that even lower but still strong ownership could provide an incentive for profit-shifting. However, all of our results are robust to majority ownership, which is important to avoid results due to "tunneling" (i.e., the phenomenon

\footnotetext{
${ }^{21}$ Following Orbis, we use the more technical term GUO; however, this is exactly the same as our description of an MNE.
} 
of individual or family shareholders who control a group of firms shifting income from firms in which they own a relatively small stake to firms in which they own a relatively large stake).

To construct our composite tax variable for estimating equation (1), we collect statutory tax rates from Ernst \& Young's Worldwide Corporate Tax Guide. Deveraux and Mafini (2007) and many others henceforth use statutory (as opposed to effective) tax rates and justify this as follows. Multinationals shift profits among affiliates they already operate. Thus, they exploit tax allowances, which depend on differences in statutory (and not effective) tax rates. If multinationals were to decide where to produce (country, location) or measure an investment's value via the margin, effective average tax rate is preferred.

From this initial sample, we exclude subsidiaries in the same countries as their GUOs in order to capture the propagation of earnings among related subsidiaries in different countries due to tax differences. This yields a sample of 49,418 subsidiaries in 90 countries from 2009 to 2017. The total number of subsidiary-year observations is 254,262 .

As discussed, we are interested in the negative responses of $E B T$ to $C T$ in equation (1) when $C T$ is positive (i.e., an increase in $C T$ via an increase in $\tau_{s}$ leads subsidiaries to send more profits abroad and thus reduces domestic EBT). This the case for 80,939 observations for 18,966 subsidiaries in 72 countries, for which we obtain our profit-shifting measure.

We merge this sample of subsidiaries with the variables needed to estimate equation (3). To determine how democracy affects profit-shifting in our regression analysis, we multiply our profit-shifting index by -1 . We have several missing data, especially for subsidiary and MNEs characteristics. The sample with nonmissing important variables is thus smaller than the sample with profit-shifting estimates; it includes 27,103 observations for 6,590 subsidiaries in 57 countries. 
Table B1. Country List and Rank According to Their Profit-Shifting

This table reports average profit-shifting estimates by country and lists the 57 countries in our analysis.

\begin{tabular}{|c|c|c|c|}
\hline Country & Profit-Shifting & Country & Profit-Shifting \\
\hline US & 1.983 & Kenya & 0.352 \\
\hline Japan & 1.236 & Croatia & 0.349 \\
\hline India & 1.196 & Mexico & 0.324 \\
\hline Philippines & 1.187 & Estonia & 0.303 \\
\hline Zambia & 1.101 & Poland & 0.302 \\
\hline Brazil & 1.062 & Israel & 0.279 \\
\hline Belgium & 1.049 & Romania & 0.278 \\
\hline Argentina & 1.029 & Peru & 0.272 \\
\hline France & 0.931 & Czech Republic & 0.252 \\
\hline Finland & 0.827 & Hungary & 0.252 \\
\hline Pakistan & 0.810 & Indonesia & 0.220 \\
\hline Colombia & 0.783 & Russia & 0.216 \\
\hline Italy & 0.762 & Serbia & 0.193 \\
\hline Australia & 0.706 & Portugal & 0.180 \\
\hline Morocco & 0.688 & Ghana & 0.145 \\
\hline Greece & 0.647 & Uganda & 0.058 \\
\hline Vietnam & 0.620 & Turkey & 0.046 \\
\hline Uruguay & 0.610 & Bangladesh & 0.031 \\
\hline Germany & 0.599 & & \\
\hline South Africa & 0.567 & & \\
\hline Gabon & 0.559 & & \\
\hline New Zealand & 0.541 & & \\
\hline Singapore & 0.531 & & \\
\hline United Kingdom & 0.520 & & \\
\hline Luxembourg & 0.489 & & \\
\hline Spain & 0.471 & & \\
\hline Sweden & 0.465 & & \\
\hline South Korea & 0.445 & & \\
\hline Denmark & 0.441 & & \\
\hline Malaysia & 0.431 & & \\
\hline Netherlands & 0.419 & & \\
\hline China & 0.410 & & \\
\hline Norway & 0.400 & & \\
\hline Canada & 0.388 & & \\
\hline Nigeria & 0.373 & & \\
\hline Austria & 0.369 & & \\
\hline Ukraine & 0.367 & & \\
\hline Slovakia & 0.362 & & \\
\hline Sri Lanka & 0.361 & & \\
\hline
\end{tabular}


Table B2. Country Ranking According to Their Statutory Tax Rate

This table reports average statutory tax rates by country for the 57 countries in our analysis.

\begin{tabular}{|c|c|c|c|c|c|}
\hline Country & Mean & Std. Dev. & Country & Mean & Std. Dev. \\
\hline Japan & 0.354 & 0.038 & United Kingdom & 0.226 & 0.032 \\
\hline Argentina & 0.350 & 0 & Finland & 0.224 & 0.033 \\
\hline US & 0.350 & 0 & Portugal & 0.222 & 0.018 \\
\hline Zambia & 0.350 & 0 & South Korea & 0.220 & 0 \\
\hline Gabon & 0.342 & 0.020 & Slovakia & 0.215 & 0.014 \\
\hline Brazil & 0.340 & 0 & Estonia & 0.206 & 0.005 \\
\hline Belgium & 0.340 & 0 & Croatia & 0.200 & 0 \\
\hline India & 0.338 & 0.009 & Russia & 0.200 & 0 \\
\hline Pakistan & 0.338 & 0.016 & Turkey & 0.200 & 0 \\
\hline France & 0.333 & 0 & Czech Republic & 0.190 & 0 \\
\hline South Africa & 0.329 & 0.033 & Hungary & 0.190 & 0 \\
\hline Sri Lanka & 0.315 & 0.049 & Poland & 0.190 & 0 \\
\hline Morocco & 0.303 & 0.005 & Singapore & 0.170 & 0 \\
\hline Italy & 0.302 & 0.030 & Romania & 0.160 & 0 \\
\hline Australia & 0.300 & 0 & Serbia & 0.150 & 0 \\
\hline Kenya & 0.300 & 0 & Total & 0.271 & 0.054 \\
\hline Mexico & 0.300 & 0 & & & \\
\hline Nigeria & 0.300 & 0 & & & \\
\hline Philippines & 0.300 & 0 & & & \\
\hline Uganda & 0.300 & 0 & & & \\
\hline Germany & 0.296 & 0.001 & & & \\
\hline Peru & 0.294 & 0.009 & & & \\
\hline Colombia & 0.291 & 0.044 & & & \\
\hline Luxembourg & 0.288 & 0.008 & & & \\
\hline New Zealand & 0.283 & 0.007 & & & \\
\hline Spain & 0.276 & 0.025 & & & \\
\hline Bangladesh & 0.275 & 0 & & & \\
\hline Greece & 0.275 & 0.021 & & & \\
\hline Norway & 0.269 & 0.016 & & & \\
\hline Canada & 0.265 & 0 & & & \\
\hline Israel & 0.251 & 0.010 & & & \\
\hline Netherlands & 0.251 & 0.002 & & & \\
\hline Austria & 0.250 & 0 & & & \\
\hline China & 0.250 & 0 & & & \\
\hline Ghana & 0.250 & 0 & & & \\
\hline Indonesia & 0.250 & 0 & & & \\
\hline Ukraine & 0.250 & 0 & & & \\
\hline Uruguay & 0.250 & 0 & & & \\
\hline Malaysia & 0.246 & 0.005 & & & \\
\hline Denmark & 0.234 & 0.014 & & & \\
\hline Sweden & 0.232 & 0.021 & & & \\
\hline Vietnam & 0.227 & 0.023 & & & \\
\hline
\end{tabular}


Table B3. Correlation Matrix of Main Variables by Country-Year

\begin{tabular}{|c|c|c|c|c|c|c|c|c|c|c|}
\hline & 1 & 2 & 3 & 4 & 5 & 6 & 7 & 8 & 9 & 10 \\
\hline 1. Democracy polity & 1 & & & & & & & & & \\
\hline 2. Competitiveness of executive recruitment & $0.888 *$ & 1 & & & & & & & & \\
\hline 3. Openness of executive recruitment & $0.448 *$ & $0.641 *$ & 1 & & & & & & & \\
\hline 4. Executive constraints & $0.950 *$ & $0.808^{*}$ & $0.405 *$ & 1 & & & & & & \\
\hline 5. Competitiveness of participation & $0.891 *$ & $0.703^{*}$ & $0.223 *$ & $0.761 *$ & 1 & & & & & \\
\hline 6. Democracy FH & $0.963 *$ & $0.836^{*}$ & $0.356^{*}$ & $0.927 *$ & $0.853 *$ & 1 & & & & \\
\hline 7. Democracy BMR & $0.873 *$ & $0.776^{*}$ & $0.403 *$ & $0.887^{*}$ & $0.736^{*}$ & $0.853 *$ & 1 & & & \\
\hline 8. Control of corruption & $0.499 *$ & $0.379 *$ & $0.212 *$ & $0.449 *$ & $0.539 *$ & $0.604 *$ & $0.381 *$ & 1 & & \\
\hline 9. Rule of law & $0.524 *$ & $0.390 *$ & $0.176^{*}$ & $0.472 *$ & $0.573 *$ & $0.636^{*}$ & $0.396 *$ & $0.973^{*}$ & 1 & \\
\hline 10. Regulatory quality & $0.539 *$ & $0.413^{*}$ & $0.195 *$ & $0.500 *$ & $0.559 *$ & $0.646^{*}$ & $0.414^{*}$ & $0.938 *$ & $0.952 *$ & 1 \\
\hline
\end{tabular}




\section{Table B4. List of Additional Country-Year Control Variables}

The table provides a list of more than 50 control variables we use in additional regressions. We do not report the results from these regressions, but the effect of Democracy polity is similar to that in our baseline regressions. In some respects, we use more than one variable (i.e., from a different source) for the same country-year characteristic (e.g., Corruption). FH: Freedom House; WB: World Bank (either World Development Indicators or Quality of Governance indices); HF: Heritage Foundation; FI: Fraser Institute; V-Dem: Varieties of Democracy Measures. Many variables are \% of GDP. We acknowledge the Quality of Government Institute for their data-collection process.

\begin{tabular}{|c|c|c|c|}
\hline Variable & Source & Variable & Source \\
\hline Corruption & WB, V-Dem & HH market concentration index & WB \\
\hline Rule of law & FH, WB & Fixed broadband subscriptions & WB \\
\hline Government effectiveness & WB & Business density & WB \\
\hline Population density & WB & Renewable electricity & WB \\
\hline Population growth & WB & Various electricity production ratios & WB \\
\hline Urban population & WB & Depth of the food deficit & WB \\
\hline Military expenditure & WB & Voice and accountability & WB \\
\hline Government education expenditure & WB & Various school enrollment ratios & WB \\
\hline Age dependency ( $\%$ of labor) & WB & Literacy rate & WB \\
\hline Birth rate (per 1,000 people) & WB & Individuals using internet & WB \\
\hline $\mathrm{CO} 2$ emissions & WB & Interest payments & WB \\
\hline Death rate (per 1,00 people) & WB & Various income share held ratios & WB \\
\hline Electric power consumption & WB & International migrant stock & WB \\
\hline Various employment ratios & WB & Internally displaced persons & WB \\
\hline Foreign direct investment inflows & WB & Intentional homicides & WB \\
\hline Fertility rate & WB & Trade freedom & $\mathrm{HF}, \mathrm{FI}$ \\
\hline Forest area & WB & Freedom from government & $\mathrm{HF}$ \\
\hline Real interest rate & WB & Government integrity & $\mathrm{HF}$ \\
\hline Life expectancy at birth & WB & Business freedom & $\mathrm{HF}$ \\
\hline Mobile subscriptions & WB & Labor freedom & $\mathrm{HF}$ \\
\hline Infant mortality & WB & Monetary freedom & $\mathrm{HF}$ \\
\hline Exports of goods and services & WB & Investment freedom & $\mathrm{HF}$ \\
\hline Consumer prices & WB & Financial freedom & $\mathrm{HF}$ \\
\hline Access to sound money & FI & Tax burden & $\mathrm{HF}$ \\
\hline Government expenditures & FI & Health expenditure & WB \\
\hline Political stability & WB & Central government debt & WB \\
\hline
\end{tabular}


Table B5. Correlation Matrix

\begin{tabular}{|c|c|c|c|c|c|c|c|c|c|c|c|c|c|c|c|}
\hline & 1 & 2 & 3 & 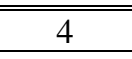 & 5 & 6 & 7 & 8 & 9 & 10 & 11 & 12 & 13 & 14 & 15 \\
\hline 1.Profit-shifting & 1 & & & & & & & & & & & & & & \\
\hline 2.Democracy polity & $-0.079 *$ & 1 & & & & & & & & & & & & & \\
\hline 3.Firm size (subsidiary) & $-0.057^{*}$ & -0.006 & 1 & & & & & & & & & & & & \\
\hline 5.Leverage (subsidiary) & $-0.034^{*}$ & $0.058 *$ & $-0.029^{*}$ & -0.007 & 1 & & & & & & & & & & \\
\hline 6.Leverage (MNE) & $-0.051^{*}$ & -0.005 & $0.068^{*}$ & $0.298^{*}$ & $0.058^{*}$ & 1 & & & & & & & & & \\
\hline 7.Tangibility (subsidiary) & $-0.035^{*}$ & 0.014 & $0.386^{*}$ & $0.105^{*}$ & $-0.183^{*}$ & $0.024^{*}$ & 1 & & & & & & & & \\
\hline 8.Tangibility (MNE) & $0.028 *$ & $-0.021^{*}$ & $0.108^{*}$ & $0.309^{*}$ & $-0.119^{*}$ & -0.011 & $0.182 *$ & 1 & & & & & & & \\
\hline 9.Cost of employees (MNE) & $-0.120 *$ & $-0.047 *$ & $0.189 *$ & $0.711^{*}$ & $0.072 *$ & $0.370^{*}$ & $0.057 *$ & $0.097 *$ & 1 & & & & & & \\
\hline 10.GDP per capita (subsidiary) & $-0.029 *$ & $0.468 *$ & $-0.027^{*}$ & $-0.094 *$ & $0.082 *$ & -0.009 & $-0.034^{*}$ & $-0.041^{*}$ & $-0.060^{*}$ & 1 & & & & & \\
\hline 11.GDP per capita (MNE) & 0.012 & 0.006 & $0.061 *$ & $0.044 *$ & $-0.019 *$ & $-0.033^{*}$ & 0.006 & -0.003 & -0.001 & $0.034 *$ & 1 & & & & \\
\hline 12.GDP growth (subsidiary) & $-0.049 *$ & $-0.195^{*}$ & $0.044^{*}$ & $-0.018 *$ & $-0.080^{*}$ & -0.014 & $0.041^{*}$ & -0.001 & $-0.041^{*}$ & $-0.302 *$ & 0.006 & 1 & & & \\
\hline 13.GDP growth (MNE) & $0.036^{*}$ & $0.047 *$ & $-0.022 *$ & $-0.084 *$ & -0.011 & $-0.063^{*}$ & $-0.034^{*}$ & $-0.038 *$ & $-0.138 *$ & $0.023^{*}$ & $-0.077 *$ & $0.173^{*}$ & 1 & & \\
\hline 14.Population (subsidiary) & $0.060 *$ & $-0.092^{*}$ & $0.111 *$ & $0.035^{*}$ & $-0.029^{*}$ & $-0.031 *$ & $0.048^{*}$ & 0.008 & $-0.026^{*}$ & $-0.589^{*}$ & $0.035^{*}$ & $0.077^{*}$ & $0.025^{*}$ & 1 & \\
\hline 15.Population (MNE) & $0.097 *$ & $0.020 *$ & $-0.027 *$ & $0.065^{*}$ & -0.001 & $0.068^{*}$ & $-0.053^{*}$ & $-0.026^{*}$ & $-0.176^{*}$ & $-0.047 *$ & $-0.336^{*}$ & $0.019^{*}$ & $-0.033 *$ & $0.049 *$ & 1 \\
\hline
\end{tabular}


Table B6. Changes in Democracy Polity by Country

This table reports the number of observations, as well as the mean, standard deviation, and number of changes (if there is a change, positive or negative) in democracy by country. The total number of observations is 27,103 , and the number of countries that experience a change in democracy is 11.

\begin{tabular}{|c|c|c|c|c|c|}
\hline Country & Observations & Mean & Std. Dev. & Democratizations & Reversals \\
\hline Argentina & 9 & 8.889 & 0.333 & 1 & \\
\hline Australia & 1,144 & 10 & 0 & & \\
\hline Austria & 203 & 10 & 0 & & \\
\hline Bangladesh & 2 & 4.5 & 2.121 & & 1 \\
\hline Belgium & 6,211 & 8 & 0 & & \\
\hline Brazil & 113 & 8 & 0 & & \\
\hline Canada & 4 & 10 & 0 & & \\
\hline China & 303 & 0 & 0 & & \\
\hline Colombia & 603 & 7 & 0 & & \\
\hline Croatia & 16 & 9 & 0 & & \\
\hline Czech Republic & 35 & 9 & 0 & & \\
\hline Denmark & 177 & 10 & 0 & & \\
\hline Estonia & 16 & 9 & 0 & & \\
\hline Finland & 15 & 10 & 0 & & \\
\hline France & 6,996 & 9 & 0 & & \\
\hline Gabon & 6 & 4 & 0 & & \\
\hline Germany & 1,467 & 10 & 0 & & \\
\hline Ghana & 4 & 8 & 0 & & \\
\hline Greece & 22 & 10 & 0 & & \\
\hline Hungary & 14 & 10 & 0 & & \\
\hline India & 625 & 9 & 0 & & \\
\hline Indonesia & 4 & 8.75 & 0.5 & 1 & \\
\hline Israel & 27 & 7 & 0 & & \\
\hline Italy & 3,326 & 10 & 0 & & \\
\hline Japan & 180 & 10 & 0 & & \\
\hline Kenya & 20 & 8.65 & 0.489 & 1 & \\
\hline Luxembourg & 229 & 10 & 0 & & \\
\hline Malaysia & 44 & 6 & 0 & & \\
\hline Mexico & 22 & 8 & 0 & & \\
\hline Morocco & 295 & 0.993 & 0.082 & 1 & \\
\hline Netherlands & 385 & 10 & 0 & & \\
\hline New Zealand & 300 & 10 & 0 & & \\
\hline Nigeria & 24 & 5.333 & 1.926 & 1 & \\
\hline Norway & 1,181 & 10 & 0 & & \\
\hline Pakistan & 44 & 6.545 & 0.504 & 2 & \\
\hline Peru & 19 & 9 & 0 & & \\
\hline Philippines & 8 & 8 & 0 & & \\
\hline Poland & 34 & 10 & 0 & & \\
\hline Portugal & 143 & 10 & 0 & & \\
\hline South Korea & 137 & 8 & 0 & & \\
\hline
\end{tabular}




\begin{tabular}{lccccc} 
Romania & 11 & 9 & 0 & & \\
Russia & 17 & 5 & 0 & \\
Serbia & 4 & 9 & 0 & \\
Singapore & 79 & 2 & 0 & 1 & \\
Slovakia & 57 & 10 & 0 & \\
South Africa & 15 & 9 & 0 & & \\
Spain & 1,642 & 10 & 0 & & \\
Sri Lanka & 2 & 5.5 & 2.121 & & \\
Sweden & 260 & 10 & 0 & & \\
Turkey & 2 & 6.5 & 3.536 & & \\
Uganda & 5 & 1 & 0 & \\
Ukraine & 8 & 6 & 0 & \\
United Kingdom & 499 & 10 & 0 & \\
US & 49 & 9.469 & 0.892 & \\
Uruguay & 6 & 10 & 0 & \\
Vietnam & 32 & 0 & 0 & \\
Zambia & 8 & 6.625 & 0.518 & \\
\hline Total & 27,103 & 8.893 & 1.630 & \\
\hline \hline
\end{tabular}


Table B7. Summary Statistics of Main Variables by Country-Year

The table reports the number of observations, mean, standard deviation, minimum, and maximum from collapsing the subsidiary-level sample by country and year.

\begin{tabular}{lccccc}
\hline \hline & Obs. & Mean & Std.Dev. & Min & Max \\
\hline Democracy polity & 340 & 7.835 & 2.891 & 0 & 10 \\
Competitiveness of executive recruitment & 340 & 2.697 & 0.660 & 0 & 3 \\
Openness of executive recruitment & 340 & 3.894 & 0.565 & 0 & 4 \\
Executive constraints & 340 & 6.171 & 1.292 & 3 & 7 \\
Competitiveness of participation & 340 & 3.962 & 1.188 & 0 & 5 \\
Democracy FH & 340 & 8.180 & 2.357 & 1.167 & 10 \\
Democracy BMR & 238 & 0.790 & 0.408 & 0 & 1 \\
Control of corruption & 340 & 0.566 & 1.112 & -1.275 & 2.405 \\
Rule of law & 340 & 0.645 & 0.986 & -1.182 & 2.096 \\
Regulatory quality & 340 & 0.717 & 0.874 & -0.951 & 2.261 \\
\hline \hline
\end{tabular}




\section{Table B8. Democracy and Profit-Shifting (Alternative Indices of Democracy): IV Estimates}

The table reports coefficients and $t$-statistics (in brackets). The dependent variable is Profit-shifting. We define all variables in Table 1 . The estimation method is IV with standard errors clustered by both subsidiary and MNE country. The lower part of the table denotes the type of fixed effects. The *,**, and $* * *$ marks denote statistical significance at the $10 \%, 5 \%$, and $1 \%$ level, respectively.

\begin{tabular}{|c|c|c|c|c|c|c|c|c|}
\hline & $(1)$ & $(2)$ & (3) & $(4)$ & $(5)$ & $(6)$ & $(7)$ & $(8)$ \\
\hline \multirow[t]{2}{*}{ Democracy FH } & $-0.206^{* *}$ & $-0.185^{* *}$ & $-0.194 * *$ & $-0.257 * * *$ & & & & \\
\hline & {$[-2.285]$} & {$[-2.021]$} & {$[-2.088]$} & {$[-2.732]$} & & & & \\
\hline \multirow[t]{2}{*}{ Democracy BMR } & & & & & $-1.335 * *$ & $-1.201 * *$ & $-1.258 * *$ & $-1.664 * * *$ \\
\hline & & & & & {$[-2.285]$} & {$[-2.021]$} & {$[-2.088]$} & {$[-2.732]$} \\
\hline \multirow[t]{2}{*}{ Firm size (subsidiary) } & $-0.013 * *$ & $-0.013 * *$ & -0.006 & -0.001 & $-0.013 * *$ & $-0.013 * *$ & -0.006 & -0.001 \\
\hline & {$[-2.408]$} & {$[-2.492]$} & [-1.496] & {$[-0.061]$} & {$[-2.408]$} & {$[-2.492]$} & {$[-1.496]$} & {$[-0.061]$} \\
\hline \multirow[t]{2}{*}{ Firm size (MNE) } & -0.008 & -0.008 & $-0.013 * * *$ & -0.020 & -0.008 & -0.008 & $-0.013 * * *$ & -0.020 \\
\hline & {$[-1.035]$} & {$[-1.102]$} & {$[-3.267]$} & {$[-1.408]$} & {$[-1.036]$} & {$[-1.102]$} & {$[-3.268]$} & {$[-1.408]$} \\
\hline \multirow[t]{2}{*}{ Leverage (subsidiary) } & 0.020 & 0.022 & 0.013 & -0.009 & 0.020 & 0.022 & 0.013 & -0.009 \\
\hline & {$[0.563]$} & {$[0.625]$} & [0.469] & {$[-0.237]$} & {$[0.563]$} & {$[0.625]$} & [0.469] & {$[-0.237]$} \\
\hline \multirow[t]{2}{*}{ Leverage (MNE) } & -0.108 & -0.111 & $-0.131 *$ & 0.019 & -0.108 & -0.111 & $-0.131 *$ & 0.019 \\
\hline & {$[-1.237]$} & {$[-1.252]$} & {$[-1.838]$} & {$[0.191]$} & {$[-1.237]$} & {$[-1.252]$} & {$[-1.838]$} & [0.191] \\
\hline \multirow[t]{2}{*}{ Tangibility (subsidiary) } & $-0.037 * * *$ & $-0.036 * *$ & -0.009 & -0.010 & $-0.037 * * *$ & $-0.036 * *$ & -0.009 & -0.010 \\
\hline & {$[-2.755]$} & {$[-2.549]$} & {$[-0.583]$} & {$[-0.448]$} & {$[-2.755]$} & {$[-2.549]$} & {$[-0.583]$} & {$[-0.448]$} \\
\hline \multirow[t]{2}{*}{ Tangibility (MNE) } & 0.085 & 0.080 & 0.113 & 0.063 & 0.085 & 0.080 & 0.113 & 0.063 \\
\hline & {$[0.805]$} & {$[0.773]$} & [1.249] & {$[0.542]$} & {$[0.805]$} & {$[0.773]$} & [1.249] & {$[0.542]$} \\
\hline \multirow[t]{2}{*}{ Cost of employees (MNE) } & $-0.028 * * *$ & $-0.027 * * *$ & $-0.030 * * *$ & 0.002 & $-0.028 * * *$ & $-0.027 * * *$ & $-0.030 * * *$ & 0.002 \\
\hline & {$[-4.887]$} & {$[-4.650]$} & {$[-6.551]$} & {$[0.180]$} & {$[-4.887]$} & {$[-4.649]$} & {$[-6.548]$} & {$[0.180]$} \\
\hline \multirow[t]{2}{*}{ GDP per capita (subsidiary) } & -0.329 & -0.453 & -0.517 & -0.762 & -0.438 & -0.550 & -0.619 & -0.897 \\
\hline & {$[-0.467]$} & {$[-0.627]$} & {$[-0.711]$} & {$[-1.161]$} & {$[-0.604]$} & {$[-0.739]$} & {$[-0.825]$} & {$[-1.311]$} \\
\hline \multirow[t]{2}{*}{ GDP per capita (MNE) } & 0.011 & 0.004 & -0.001 & $0.379 * * *$ & 0.011 & 0.004 & -0.001 & $0.379 * * *$ \\
\hline & {$[0.518]$} & {$[0.211]$} & {$[-0.070]$} & {$[5.575]$} & {$[0.518]$} & {$[0.211]$} & {$[-0.070]$} & {$[5.583]$} \\
\hline \multirow[t]{2}{*}{ GDP growth (subsidiary) } & $-0.027 *$ & $-0.055 * * *$ & $-0.057 * * *$ & $-0.073 * * *$ & -0.016 & $-0.046^{* * *}$ & $-0.047 * * *$ & $-0.059 * * *$ \\
\hline & {$[-1.735]$} & {$[-2.866]$} & {$[-2.861]$} & {$[-4.513]$} & {$[-1.462]$} & {$[-3.038]$} & {$[-2.974]$} & {$[-4.852]$} \\
\hline \multirow[t]{2}{*}{ GDP growth (MNE) } & $0.029 * *$ & $0.026 * *$ & $0.023 *$ & -0.018 & $0.029 * *$ & $0.026 * *$ & $0.023 *$ & -0.018 \\
\hline & {$[2.504]$} & {$[2.024]$} & {$[1.967]$} & {$[-1.131]$} & {$[2.503]$} & {$[2.025]$} & [1.967] & {$[-1.131]$} \\
\hline \multirow[t]{2}{*}{ Population (subsidiary) } & $5.829 * *$ & 1.017 & 1.197 & 3.133 & $5.849 * *$ & 1.035 & 1.215 & 3.157 \\
\hline & {$[2.298]$} & {$[0.602]$} & [0.689] & [1.293] & {$[2.306]$} & {$[0.613]$} & [0.699] & [1.302] \\
\hline \multirow[t]{2}{*}{ Population (MNE) } & $0.042 * * *$ & $0.040 * * *$ & $0.034 * * *$ & -0.932 & $0.042 * * *$ & $0.040 * * *$ & $0.034 * * *$ & -0.932 \\
\hline & [4.884] & [4.917] & {$[4.434]$} & {$[-0.758]$} & [4.887] & [4.919] & {$[4.435]$} & {$[-0.758]$} \\
\hline \multirow[t]{2}{*}{ Constant } & $-95.107 * *$ & -10.446 & -12.596 & -30.263 & $-95.005^{* *}$ & -10.354 & -12.500 & -30.135 \\
\hline & {$[-2.341]$} & {$[-0.369]$} & {$[-0.432]$} & {$[-0.676]$} & {$[-2.338]$} & {$[-0.366]$} & {$[-0.428]$} & {$[-0.673]$} \\
\hline Observations & 29,294 & 29,294 & 29,294 & 27,154 & 29,294 & 29,294 & 29,294 & 27,154 \\
\hline Adjusted R-squared & 0.268 & 0.275 & 0.315 & 0.779 & 0.268 & 0.275 & 0.315 & 0.779 \\
\hline Year effects & $\mathrm{N}$ & Y & Y & Y & $\mathrm{N}$ & $\mathrm{Y}$ & Y & $\mathrm{Y}$ \\
\hline Subsidiary effects & $\mathrm{N}$ & $\mathrm{N}$ & $\mathrm{N}$ & $\mathrm{Y}$ & $\mathrm{N}$ & $\mathrm{N}$ & $\mathrm{N}$ & $\mathrm{Y}$ \\
\hline Sub. country effects & $\mathrm{Y}$ & $\mathrm{Y}$ & $\mathrm{Y}$ & $\mathrm{N}$ & $\mathrm{Y}$ & $\mathrm{Y}$ & $\mathrm{Y}$ & $\mathrm{N}$ \\
\hline Sub. industry effects & $\mathrm{N}$ & $\mathrm{N}$ & $\mathrm{Y}$ & $\mathrm{N}$ & $\mathrm{N}$ & $\mathrm{N}$ & $\mathrm{Y}$ & $\mathrm{N}$ \\
\hline Clustered standard errors & country & country & country & country & country & country & country & country \\
\hline
\end{tabular}


Table B9. Excluding Countries, where Democracy changes, with less than 10 observations

The table reports coefficients and $t$-statistics (in brackets). Columns 2 to 8 , report IV estimates after dropping all countries, where democracy changes, with less than 10 observations. We drop Argentina, Bangladesh, Indonesia, Sri Lanka, Turkey, Zambia and US, respectively. We present these estimates against our baseline results, which we replicate in column 1 for convenience. The dependent variable is Profit-shifting, and all variables are defined in Table 1. Estimation method is IV with standard errors clustered by both subsidiary's and MNE's country. The lower part of the table denotes the type of fixed effects used in each specification. The $*, * *$, and $* * *$ marks denote statistical significance at the $10 \%, 5 \%$, and $1 \%$ level, respectively.

\begin{tabular}{|c|c|c|c|c|c|c|c|c|}
\hline & $(1)$ & (2) & (3) & (4) & (5) & $(6)$ & (7) & (8) \\
\hline \multirow[t]{2}{*}{ Democracy polity } & $-0.190 * * *$ & $-0.190 * * *$ & $-0.191 * * *$ & $-0.191 * * *$ & $-0.191 * * *$ & $-0.191 * * *$ & $-0.191 * * *$ & $-0.191 * * *$ \\
\hline & {$[-2.732]$} & {$[-2.728]$} & {$[-2.727]$} & {$[-2.731]$} & {$[-2.735]$} & {$[-2.737]$} & {$[-2.743]$} & {$[-2.741]$} \\
\hline \multirow[t]{2}{*}{ Firm size (subsidiary) } & -0.001 & -0.001 & -0.001 & -0.001 & -0.001 & -0.001 & -0.001 & -0.001 \\
\hline & {$[-0.061]$} & {$[-0.062]$} & {$[-0.060]$} & {$[-0.061]$} & {$[-0.059]$} & {$[-0.058]$} & {$[-0.074]$} & {$[-0.058]$} \\
\hline \multirow[t]{2}{*}{ Firm size (MNE) } & -0.020 & -0.020 & -0.020 & -0.020 & -0.020 & -0.020 & -0.020 & -0.020 \\
\hline & {$[-1.408]$} & {$[-1.412]$} & {$[-1.412]$} & {$[-1.419]$} & {$[-1.431]$} & {$[-1.429]$} & {$[-1.420]$} & {$[-1.509]$} \\
\hline \multirow[t]{2}{*}{ Leverage (subsidiary) } & -0.009 & -0.009 & -0.009 & -0.009 & -0.009 & -0.009 & -0.008 & -0.010 \\
\hline & {$[-0.237]$} & {$[-0.234]$} & {$[-0.236]$} & {$[-0.237]$} & {$[-0.233]$} & {$[-0.233]$} & {$[-0.206]$} & {$[-0.262]$} \\
\hline \multirow[t]{2}{*}{ Leverage (MNE) } & 0.019 & 0.019 & 0.019 & 0.019 & 0.020 & 0.019 & 0.019 & 0.019 \\
\hline & [0.191] & {$[0.190]$} & [0.191] & [0.189] & [0.193] & [0.192] & [0.188] & {$[0.192]$} \\
\hline \multirow[t]{2}{*}{ Tangibility (subsidiary) } & -0.010 & -0.010 & -0.010 & -0.010 & -0.010 & -0.010 & -0.009 & -0.011 \\
\hline & {$[-0.448]$} & {$[-0.447]$} & {$[-0.448]$} & {$[-0.443]$} & {$[-0.433]$} & {$[-0.434]$} & {$[-0.418]$} & {$[-0.476]$} \\
\hline \multirow{2}{*}{ Tangibility (MNE) } & 0.063 & 0.063 & 0.063 & 0.063 & 0.064 & 0.063 & 0.063 & 0.065 \\
\hline & {$[0.542]$} & [0.539] & {$[0.540]$} & {$[0.541]$} & {$[0.548]$} & [0.546] & {$[0.540]$} & {$[0.553]$} \\
\hline \multirow[t]{2}{*}{ Cost of employees (MNE) } & 0.002 & 0.002 & 0.002 & 0.002 & 0.002 & 0.002 & 0.002 & 0.002 \\
\hline & {$[0.180]$} & [0.183] & [0.183] & [0.188] & [0.184] & [0.184] & [0.175] & [0.179] \\
\hline \multirow[t]{2}{*}{ GDP per capita (subsidiary) } & -0.833 & -0.834 & -0.836 & -0.832 & -0.823 & -0.821 & -0.829 & -0.829 \\
\hline & {$[-1.241]$} & {$[-1.242]$} & {$[-1.243]$} & {$[-1.237]$} & {$[-1.223]$} & {$[-1.220]$} & {$[-1.232]$} & {$[-1.230]$} \\
\hline \multirow[t]{2}{*}{ GDP per capita (MNE) } & $0.379 * * *$ & $0.378 * * *$ & $0.378 * * *$ & $0.379 * * *$ & $0.378 * * *$ & $0.379 * * *$ & $0.378 * * *$ & $0.380 * * *$ \\
\hline & {$[5.581]$} & {$[5.535]$} & {$[5.534]$} & {$[5.569]$} & {$[5.486]$} & {$[5.530]$} & {$[5.532]$} & [5.592] \\
\hline \multirow[t]{2}{*}{ GDP growth (subsidiary) } & $-0.044 * * *$ & $-0.044 * * *$ & $-0.044 * * *$ & $-0.044 * * *$ & $-0.044 * * *$ & $-0.044 * * *$ & $-0.044 * * *$ & $-0.044 * * *$ \\
\hline & {$[-4.819]$} & {$[-4.820]$} & {$[-4.823]$} & {$[-4.817]$} & {$[-4.817]$} & {$[-4.810]$} & {$[-4.781]$} & {$[-4.782]$} \\
\hline \multirow[t]{2}{*}{ GDP growth (MNE) } & -0.018 & -0.018 & -0.018 & -0.018 & -0.018 & -0.018 & -0.018 & -0.018 \\
\hline & {$[-1.131]$} & {$[-1.120]$} & {$[-1.120]$} & {$[-1.123]$} & {$[-1.122]$} & {$[-1.123]$} & {$[-1.133]$} & {$[-1.136]$} \\
\hline \multirow[t]{2}{*}{ Population (subsidiary) } & 3.160 & 3.164 & 3.165 & 3.169 & 3.165 & 3.169 & 3.243 & 3.236 \\
\hline & [1.303] & [1.304] & [1.305] & [1.306] & [1.304] & [1.305] & [1.324] & [1.322] \\
\hline \multirow[t]{2}{*}{ Population (MNE) } & -0.932 & -0.938 & -0.937 & -0.941 & -0.929 & -0.927 & -0.911 & -0.908 \\
\hline & {$[-0.758]$} & {$[-0.763]$} & {$[-0.763]$} & {$[-0.766]$} & {$[-0.753]$} & {$[-0.751]$} & {$[-0.740]$} & {$[-0.739]$} \\
\hline \multirow[t]{2}{*}{ Constant } & -30.688 & -30.631 & -30.635 & -30.676 & -30.916 & -31.049 & -32.515 & -32.445 \\
\hline & {$[-0.685]$} & {$[-0.683]$} & {$[-0.684]$} & {$[-0.684]$} & {$[-0.688]$} & {$[-0.691]$} & {$[-0.718]$} & {$[-0.717]$} \\
\hline Observations & 27,154 & 27,145 & 27,143 & 27,139 & 27,137 & 27,135 & 27,127 & 27,078 \\
\hline Adjusted R-squared & 0.779 & 0.779 & 0.779 & 0.779 & 0.779 & 0.779 & 0.780 & 0.778 \\
\hline Year effects & $\mathrm{Y}$ & $\mathrm{Y}$ & $\mathrm{Y}$ & $\mathrm{Y}$ & $\mathrm{Y}$ & $\mathrm{Y}$ & $\mathrm{Y}$ & $\mathrm{Y}$ \\
\hline Subsidiary effects & $\mathrm{Y}$ & $\mathrm{Y}$ & $\mathrm{Y}$ & $\mathrm{Y}$ & $\mathrm{Y}$ & Y & $\mathrm{Y}$ & $\mathrm{Y}$ \\
\hline Sub.Country effects & $\mathrm{N}$ & $\mathrm{N}$ & $\mathrm{N}$ & $\mathrm{N}$ & $\mathrm{N}$ & $\mathrm{N}$ & $\mathrm{N}$ & $\mathrm{N}$ \\
\hline Sub.Industry effects & $\mathrm{N}$ & $\mathrm{N}$ & $\mathrm{N}$ & $\mathrm{N}$ & $\mathrm{N}$ & $\mathrm{N}$ & $\mathrm{N}$ & $\mathrm{N}$ \\
\hline Clustered standard errors & country & country & country & country & country & country & country & country \\
\hline
\end{tabular}


Table B10. Winsorizing data

The table reports coefficients and $t$-statistics (in brackets). The dependent variable is Profit-shifting, and all variables are defined in Table 1. Estimation method is OLS for the first two columns and IV for columns (3) and (4), with standard errors clustered by both subsidiary's and MNE's country. The lower part of the table denotes the type of fixed effects used in each specification. The *, **, and *** marks denote statistical significance at the $10 \%, 5 \%$, and $1 \%$ level, respectively.

\begin{tabular}{|c|c|c|c|c|}
\hline & (1) & (2) & (3) & (4) \\
\hline Democracy polity & $\begin{array}{c}-0.114 * * \\
{[-2.646]}\end{array}$ & $\begin{array}{c}-0.134 * * \\
{[-2.470]}\end{array}$ & & \\
\hline Democracy polity (IV) & & & $\begin{array}{l}-0.141^{*} \\
{[-1.949]}\end{array}$ & $\begin{array}{c}-0.183 * * \\
{[-2.561]}\end{array}$ \\
\hline Firm size (subsidiary) & $\begin{array}{c}-0.005 \\
{[-1.448]}\end{array}$ & $\begin{array}{c}0.002 \\
{[0.265]}\end{array}$ & $\begin{array}{c}-0.006 \\
{[-1.509]}\end{array}$ & $\begin{array}{c}0.002 \\
{[0.195]}\end{array}$ \\
\hline Firm size (MNE) & $\begin{array}{c}-0.013 * * * \\
{[-2.944]}\end{array}$ & $\begin{array}{c}-0.017 \\
{[-1.242]}\end{array}$ & $\begin{array}{c}-0.012 * * * \\
{[-2.983]}\end{array}$ & $\begin{array}{c}-0.014 \\
{[-0.993]}\end{array}$ \\
\hline Leverage (subsidiary) & $\begin{array}{c}0.016 \\
{[0.599]}\end{array}$ & $\begin{array}{c}-0.006 \\
{[-0.209]}\end{array}$ & $\begin{array}{c}0.015 \\
{[0.530]}\end{array}$ & $\begin{array}{c}-0.009 \\
{[-0.254]}\end{array}$ \\
\hline Leverage (MNE) & $\begin{array}{c}-0.140 * * \\
{[-2.011]}\end{array}$ & $\begin{array}{c}-0.001 \\
{[-0.007]}\end{array}$ & $\begin{array}{l}-0.137 * \\
{[-1.989]}\end{array}$ & $\begin{array}{c}0.005 \\
{[0.040]}\end{array}$ \\
\hline Tangibility (subsidiary) & $\begin{array}{c}-0.009 \\
{[-0.679]}\end{array}$ & $\begin{array}{c}-0.011 \\
{[-0.530]}\end{array}$ & $\begin{array}{c}-0.008 \\
{[-0.630]}\end{array}$ & $\begin{array}{c}-0.010 \\
{[-0.478]}\end{array}$ \\
\hline Tangibility (MNE) & $\begin{array}{c}0.100 \\
{[1.129]}\end{array}$ & $\begin{array}{c}0.062 \\
{[0.529]}\end{array}$ & $\begin{array}{c}0.111 \\
{[1.244]}\end{array}$ & $\begin{array}{c}0.074 \\
{[0.633]}\end{array}$ \\
\hline Cost of employees (MNE) & $\begin{array}{c}-0.029 * * * \\
{[-5.446]}\end{array}$ & $\begin{array}{c}0.004 \\
{[0.321]}\end{array}$ & $\begin{array}{c}-0.029 * * * \\
{[-5.518]}\end{array}$ & $\begin{array}{c}0.002 \\
{[0.169]}\end{array}$ \\
\hline GDP per capita (subsidiary) & $\begin{array}{c}-0.724 \\
{[-1.113]}\end{array}$ & $\begin{array}{c}-0.797 \\
{[-1.289]}\end{array}$ & $\begin{array}{c}-0.787 \\
{[-1.135]}\end{array}$ & $\begin{array}{c}-0.875 \\
{[-1.272]}\end{array}$ \\
\hline GDP per capita (MNE) & $\begin{array}{c}0.001 \\
{[0.035]}\end{array}$ & $\begin{array}{c}0.327 * * * \\
{[3.627]}\end{array}$ & $\begin{array}{c}-0.000 \\
{[-0.006]}\end{array}$ & $\begin{array}{c}0.327 * * * \\
{[4.390]}\end{array}$ \\
\hline GDP growth (subsidiary) & $\begin{array}{c}-0.028 * * \\
{[-2.248]}\end{array}$ & $\begin{array}{c}-0.032 * * \\
{[-2.540]}\end{array}$ & $\begin{array}{c}-0.040 * * * \\
{[-2.937]}\end{array}$ & $\begin{array}{c}-0.047 * * * * \\
{[-3.732]}\end{array}$ \\
\hline GDP growth (MNE) & $\begin{array}{l}0.029^{*} \\
{[1.721]}\end{array}$ & $\begin{array}{c}-0.023 \\
{[-0.970]}\end{array}$ & $\begin{array}{c}0.029 \\
{[1.620]}\end{array}$ & $\begin{array}{c}-0.023 \\
{[-0.987]}\end{array}$ \\
\hline Population (subsidiary) & $\begin{array}{c}1.886 \\
{[0.955]}\end{array}$ & $\begin{array}{c}3.878 \\
{[1.471]}\end{array}$ & $\begin{array}{c}1.590 \\
{[0.845]}\end{array}$ & $\begin{array}{c}3.455 \\
{[1.362]}\end{array}$ \\
\hline Population (MNE) & $\begin{array}{c}0.036^{* * * *} \\
{[4.791]}\end{array}$ & $\begin{array}{c}-1.741 \\
{[-1.196]}\end{array}$ & $\begin{array}{c}0.036^{* * * *} \\
{[4.647]}\end{array}$ & $\begin{array}{c}-1.417 \\
{[-1.001]}\end{array}$ \\
\hline Constant & $\begin{array}{l}-23.362 \\
{[-0.700]}\end{array}$ & $\begin{array}{c}-29.331 \\
{[-0.588]} \\
\end{array}$ & $\begin{array}{l}-17.214 \\
{[-0.529]}\end{array}$ & $\begin{array}{l}-26.399 \\
{[-0.547]}\end{array}$ \\
\hline Observations & 29,241 & 27,103 & 29,294 & 27,154 \\
\hline Adjusted R-squared & 0.316 & 0.777 & 0.318 & 0.780 \\
\hline Year effects & $\mathrm{Y}$ & $\mathrm{Y}$ & $\mathrm{Y}$ & $\mathrm{Y}$ \\
\hline Subsidiary effects & $\mathrm{N}$ & $\mathrm{Y}$ & $\mathrm{N}$ & $\mathrm{Y}$ \\
\hline Sub.Country effects & $\mathrm{Y}$ & $\mathrm{N}$ & $\mathrm{Y}$ & $\mathrm{N}$ \\
\hline $\begin{array}{l}\text { Sub.Industry effects } \\
\text { Clustered standard errors }\end{array}$ & $\begin{array}{c}\mathrm{Y} \\
\text { country }\end{array}$ & $\begin{array}{c}\mathrm{N} \\
\text { country }\end{array}$ & $\begin{array}{c}\mathrm{Y} \\
\text { country }\end{array}$ & $\begin{array}{c}\mathrm{N} \\
\text { country }\end{array}$ \\
\hline
\end{tabular}

